\title{
Article \\ The Historical Development of Constructed Wetlands for Wastewater Treatment
}

\author{
Jan Vymazal (1)
}

Citation: Vymazal, J. The Historical Development of Constructed Wetlands for Wastewater Treatment. Land 2022, 11, 174. https://doi.org/ 10.3390/land11020174

Academic Editor: Richard C. Smardon

Received: 2 December 2021 Accepted: 5 January 2022

Published: 21 January 2022

Publisher's Note: MDPI stays neutral with regard to jurisdictional claims in published maps and institutional affiliations.

Copyright: (C) 2022 by the author. Licensee MDPI, Basel, Switzerland. This article is an open access article distributed under the terms and conditions of the Creative Commons Attribution (CC BY) license (https:// creativecommons.org/licenses/by/ $4.0 /)$.
Faculty of Environmental Sciences, Czech University of Life Sciences Prague, Kamýcká 129, 16521 Prague, Czech Republic; vymazal@fzp.czu.cz

\begin{abstract}
Constructed wetlands (CWs) for wastewater treatment are engineered systems that are designed and operated in order to use all natural processes involved in the removal of pollutants from wastewaters. CWs are designed to take advantage of many of the same processes that occur in natural wetlands, but do so within a more controlled environment. The basic classification is based on the presence/absence of wastewater on the wetland surface. The subsurface flow of CWs can be classified according to the direction of the flow to horizontal and vertical. The combination of various types of CWs is called hybrid CW. The CWs technology began in the 1950s in Germany, but the major extension across the world occurred during the 1990s and early 2000s. The early CWs in Germany were designed as hybrid CWs; however, during the 1970s and 1980s, horizontal subsurface flow CWs were mostly designed. The stricter limits for nitrogen, and especially ammonia, applied in Europe during the 1990s, brought more attention to vertical subsurface flow and hybrid systems. Constructed wetlands have been used to treat various types of wastewater, including sewage, industrial and agricultural wastewaters, various drainage and runoff waters and landfill leachate. Recently, more attention has also been paid to constructed treatment wetlands as part of a circular economy in the urban environments: it is clear that CWs are a good fit for the new concept of sponge cities.
\end{abstract}

Keywords: constructed wetlands; macrophytes; pollution; wastewater

\section{Introduction}

Wetlands are transitional environments. In a spatial context, they lie between dry land and open water at the coast, around inland lakes and rivers or as mires draped across the landscape. In an ecological context, wetlands are intermediate between terrestrial and aquatic ecosystems. In a temporal context, most wetlands are destined either to evolve into dry land as a result of lowered water tables, sedimentation and plant succession, or to be submerged by rising water tables associated with relative sea-level rise or climatic change. Wetlands often form part of a large continuum of community type, and therefore it is difficult to set boundaries [1].

Wetlands can be defined as areas flooded with shallow water, or soil is saturated with water for long enough to create hydric soils that support specialized macrophytes adapted to life in anaerobic conditions [1,2]. However, Mitsch and Gosselink [1] pointed out that although the concepts of shallow water or saturated conditions, unique wetland soils and vegetation adapted to wet conditions are fairly straightforward, combining these three factors to obtain a precise definition is difficult, due to a number of characteristics that distinguish wetlands from other ecosystems, yet make them less easy to define.

Natural wetlands have been used for wastewater treatment for centuries. In many cases, however, the reasoning behind this use was disposal rather than treatment, and the wetland simply served as a convenient recipient that was closer than the nearest river or other waterways [3]. Such uncontrolled wastewater disposal led to the destruction of many wetlands around the world. The attempts to use natural wetlands for wastewater treatment under controlled conditions continued even in the 1970s and 1980s, especially in the United 
States [4-6]. The experiments with natural wetlands revealed the difficulties with system maintenance and, also, the treatment efficiency was quite unpredictable. Therefore, the use of natural wetlands to treat wastewater was replaced with the use of constructed wetlands (CWs), which have been developed since the 1960s.

Constructed wetlands designed to treat wastewater are engineered systems that are built to utilize natural wetland processes involved in the transformation and removal of pollutants, but under more controlled conditions. Constructed wetlands can be built with a greater degree of control than natural systems, thus allowing the construction of treatment facilities with a well-defined composition of substrates, vegetation types and flow patterns. In addition, constructed wetlands offer several additional advantages compared to natural wetlands, including site selection, flexibility in sizing and, most importantly, control over the hydraulic pathways and retention time [7]. Plants are an indispensable part of constructed wetlands; however, their role in pollution removal is rather indirect, such as the insulation of subsurface flow systems, provision of oxygen to otherwise anoxic substrates, provision of surface for attached bacteria, excretion of antibacterial compounds from the roots and the reduction of wind allowing better sedimentation of the suspended solids in surface flow CWs. The direct role is restricted to the uptake of nutrients if the biomass is harvested [8-10].

\section{Classification of Constructed Wetlands for Wastewater Treatment}

The most comprehensive classification of constructed treatment wetlands was published by Fonder and Headley [11], who pointed out that there are three main characteristics typical of these systems: the presence of macrophytes, the existence of water-logged or saturated substrate conditions for at least part of the time and the inflow of contaminated water with constituents to be removed. Based on the predominant position of the water in the system, two major groups can be recognized: surface flow CWs (sometimes called free water surface $\mathrm{CWs}$ ) and subsurface flow CWs. Subsurface flow systems can be further classified as horizontal and vertical, according to the direction of the flow.

\subsection{Surface Flow Constructed Wetlands}

Surface flow constructed wetlands usually consist of shallow basins or channels with soil or other suitable mediums, to support the growth of macrophytes if rooted macrophytes are present. One of their primary design purposes is to contact slow-flowing wastewater with reactive biological surfaces [12].

Surface flow CWs can be classified according to the macrophyte type into CWs with (a) free-floating macrophytes, (b) floating-leaved macrophytes, (c) submerged macrophytes, (d) emergent macrophytes and (e) trees [13]. In surface flow constructed wetlands, the organics are removed principally by the bacterial metabolism of both attached and freeliving bacteria. Bacteria can be attached to either the roots and rhizomes of free-floating plants, or to the stems and leaves of rooting macrophytes. The removal of suspended solids occurs through gravity sedimentation. The plants minimize the wind-induced turbulence and water stirring, allowing for effective sedimentation [8]. The removal of nitrogen is primarily executed by denitrification, while ammonia volatilization and plant uptake play minor roles. Nitrification occurs in most surface flow constructed wetlands, but this process does not remove nitrogen from wastewater and only transfers ammonia to nitrate. The removal through denitrification can take place in a layer of decomposed plant material at the bottom of the wetland. Phosphorus removal is generally very low because of the limited contact of wastewater with soil particles; therefore, there is a limited precipitation with $\mathrm{Fe}, \mathrm{Al}, \mathrm{Mg}$ or $\mathrm{Ca}$ [14].

\subsubsection{CWs with Free-Floating Macrophytes}

Free-floating macrophytes are highly diverse in form and habitat, ranging from large plants, such as Eichhornia crassipes (water hyacinth, Figure 1) or Pistia stratiotes (water lettuce) with large leaves and roots, compared to very small plants, such as Lemnaceae (duckweeds, 
e.g., Lemna spp., Sprodela polyrhiza or Wolffia spp.) with tiny roots [15]. Free-floating plants are highly productive and belong to the fastest growing plants on the planet. E. crassipes and P. stratiotes are frost sensitive and do not survive in temperate and cold climatic conditions, and are restricted to the tropics and subtropics. On the other hand, Lemnaceae (Figure 2) have a much wider geographic range as they are able to survive even under light frost [16]. Constructed wetlands with free-floating macrophytes were intensively studied in the late 1970s and the early 1980s, but the high operation and maintenance costs were connected with the constant need of plant harvesting, and the subsequent disposal prevented the use of these systems from a wider application $[17,18]$. It is important to say that duckweed can naturally occur in all types of surface flow constructed wetlands, as these plants can easily be transported by wind or by birds.

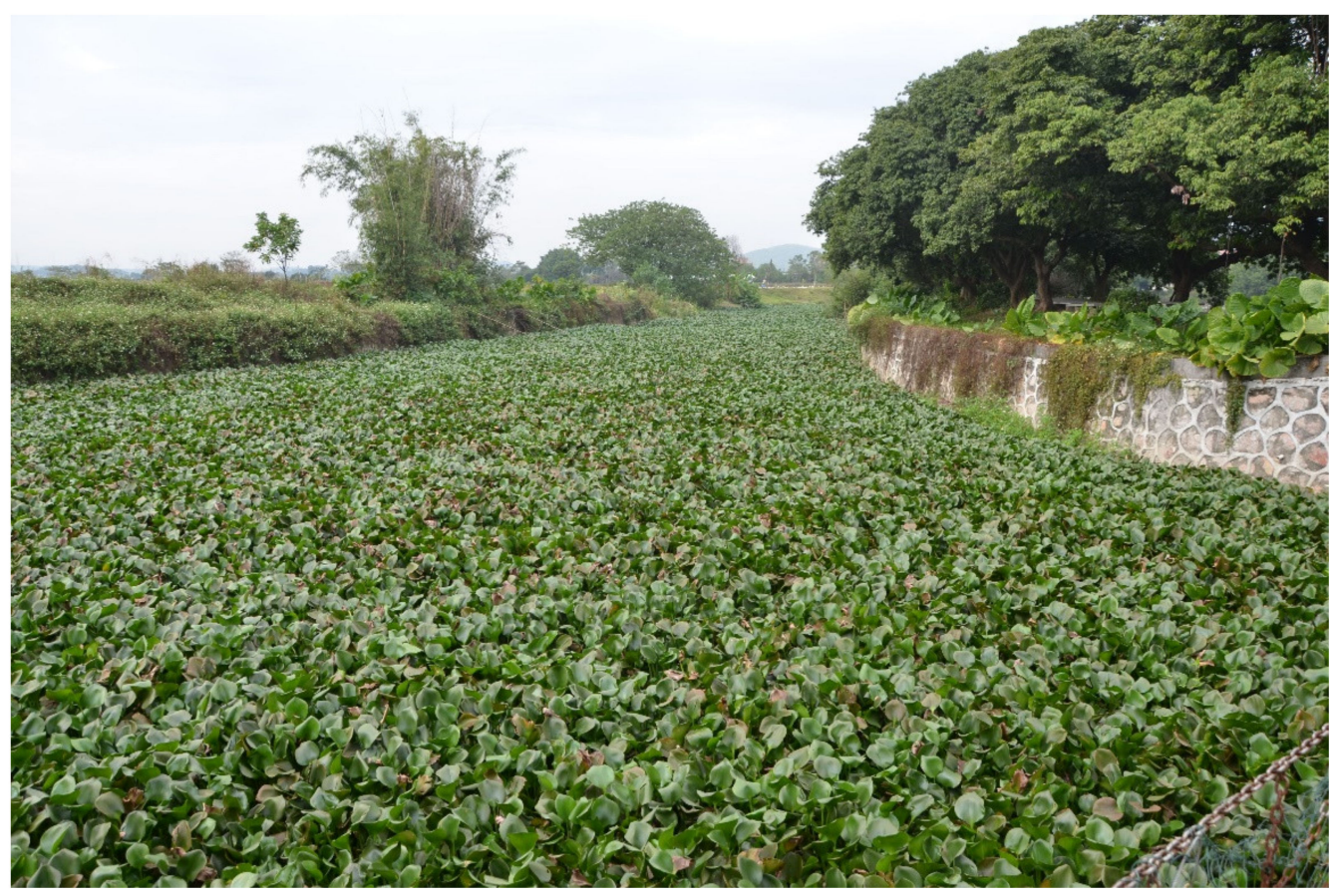

Figure 1. Surface flow constructed wetlands with Eichhornia crassipes (water hyacinth) in Langtou near Guangzhou, China. Photo Jan Vymazal.

\subsubsection{CW with Floating-Leaved Macrophytes}

Floating-leaved macrophytes (Figure 3) include plant species that are rooted in the substrate, and their leaves on long peduncles float on the water's surface. Typical examples of this type of macrophyte are water lilies (Nymphaea spp.), spatterdock (Nuphar lutea) or Indian lotus (Nelumbo nucifera). The plants in this group usually have large rhizomes and leaves floating on the water's surface connected to the rhizomes with long peduncles. So far, only several constructed wetlands have used floating-leaved macrophytes. 


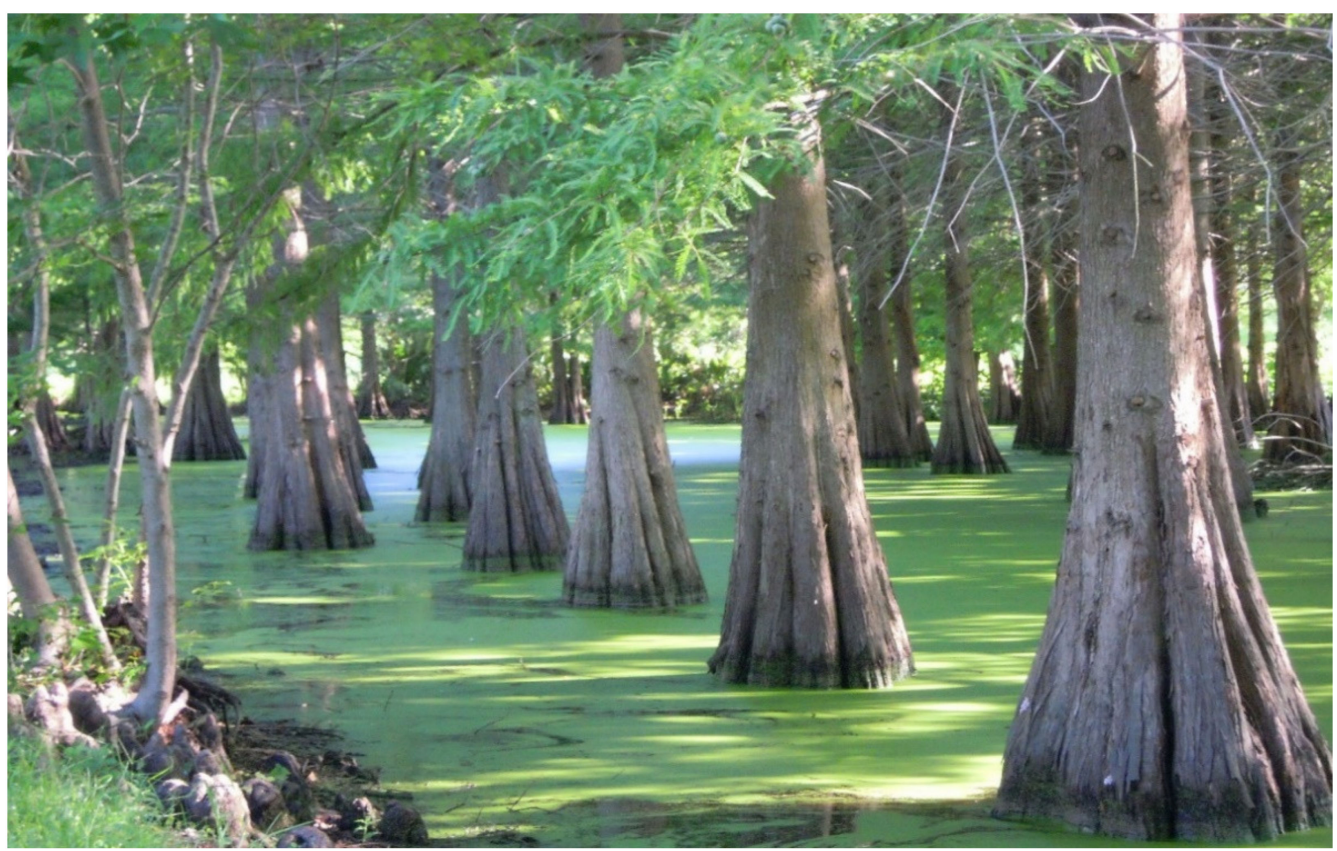

Figure 2. Constructed wetland with Lemna spp. (duckweed) and Taxodium distichum (baldcypress) designed to treat stormwater runoff in Orlando, Florida. Photo: Jan Vymazal.

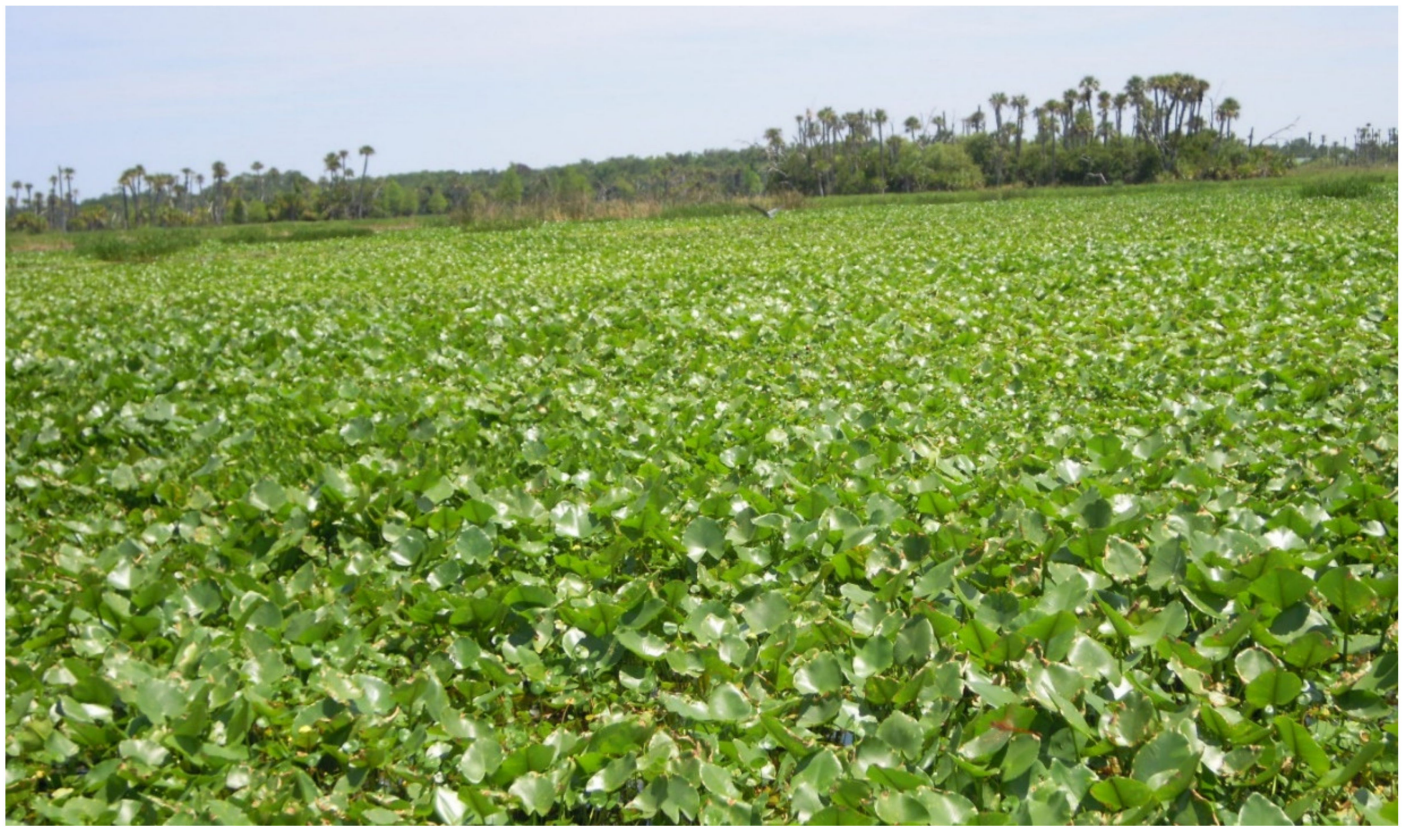

Figure 3. Constructed wetland (Ironbridge, Florida) planted with Nuphar lutea (spatterdock), designed for tertiary treatment of 800,000 PE in Orlando, Florida. Photo Jan Vymazal.

\subsubsection{CW with Submerged Macrophytes}

Submerged macrophytes root in the sediment and the entire plant is submerged in a water column. Submerged plants take up nutrients from the sediments; however, it has been discovered that at least some plants are able to absorb the nutrients directly from the water column $[19,20]$. The use of submerged macrophytes is restricted to well-oxygenated waters with low concentrations of suspended solids. High concentrations of suspended solids can limit the penetration of PHAR (photosynthetically active radiation) necessary for full photosynthesis. Therefore, it has been recommended to use submerged macrophytes 
for constructed wetlands designed for tertiary treatment [7]. There is wide variety of species that can be used for constructed wetlands and have been used in laboratory or small-scale systems; however, in full-scale constructed wetlands, Myriophyllum spicatum (watermilfoil, Figure 4) has mostly been used $[13,21]$. In some systems, naturally occurring species were used, such as in the case of the Florida Everglades Stormwater Area constructed wetlands, in which Najas guadalupensis (southern naiad) and Ceratophyllum demersum (coontail) are present. Submerged plants are naturally covered by periphyton (algal-based assemblage). Periphyton has a beneficial effect on pollutant removal through the release of oxygen necessary for the oxidation of pollutants as well as the uptake of nutrients. On the other hand, the excessive growth of periphyton can seriously limit the photosynthesis of submerged macrophytes by blocking the PHAR [22].

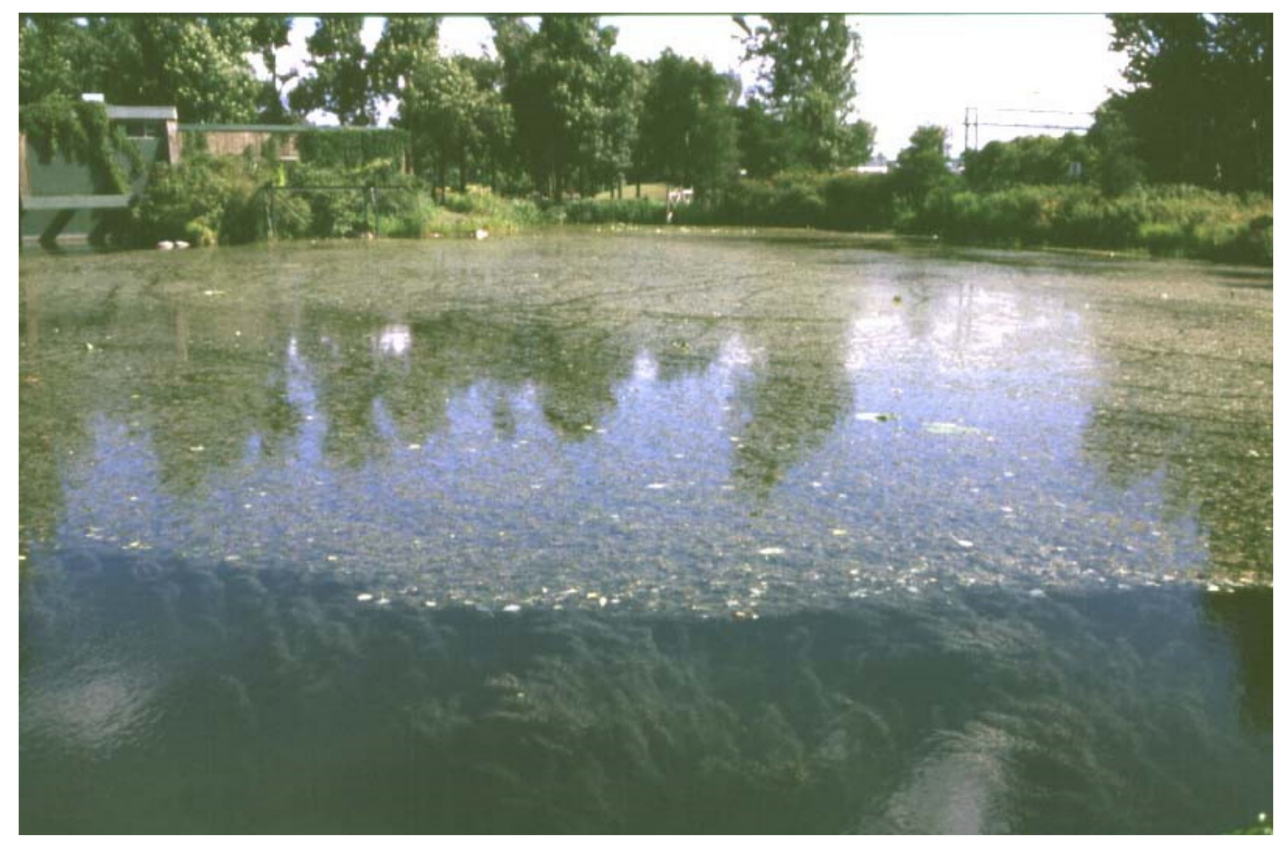

Figure 4. Surface flow CW with submerged macrophytes (mostly Myriophyllum spicatum, water milfoil) in Montréal, Canada. Photo Jan Vymazal.

\subsubsection{CWs with Emergent Macrophytes}

A typical surface flow $\mathrm{CW}$ with emergent macrophytes (Figure 5) consists of a shallow basin or sequence of basins, containing $20-30 \mathrm{~cm}$ of rooting soil, with a water depth of $10-60 \mathrm{~cm}$ and a dense stand of macrophytes. The most common plants used in this type of CW are Phragmites australis (common reed), Typha spp. (cattails) and Scirpus/Schoenoplectus spp. (bulrushes) [23]. The shallow water depth, low flow velocity and presence of the plant stalks and litter regulate the water flow and, especially in long, narrow channels, ensure plug-flow conditions [24].

Typically, surface flow constructed wetlands have aerated zones, especially near the water surface, due to atmospheric diffusion and the production of oxygen by the photosynthetic activity of algae and cyanobacteria. The anoxic and even anaerobic conditions can occur near the bottom and especially within the layer of decaying plant material. 


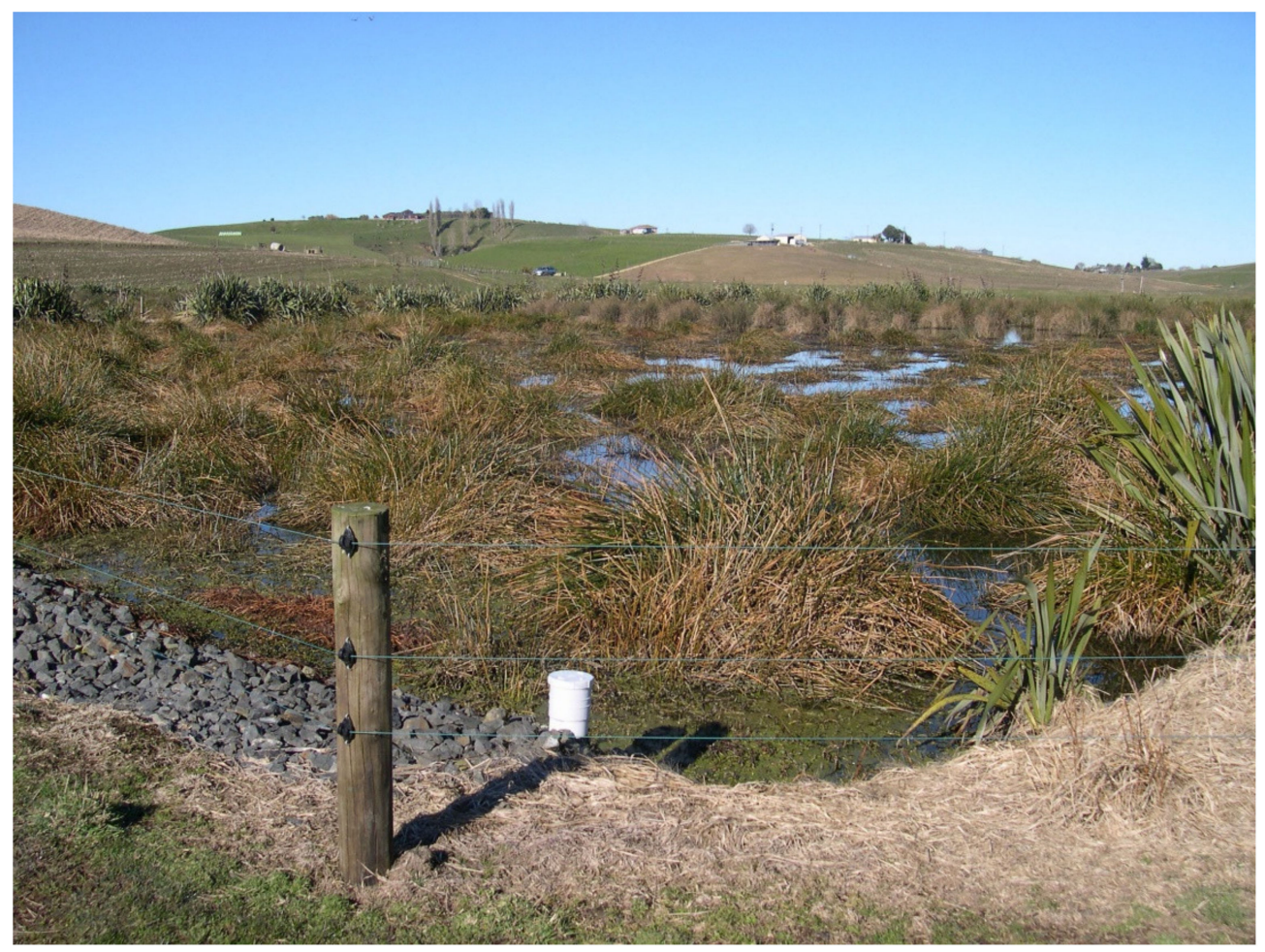

Figure 5. Surface flow $\mathrm{CW}$ with emergent plants (Eleocharis sphacelata, tall spikerush). Otorohanga, New Zealand. Photo Jan Vymazal.

In Europe, this technology started during the late 1960s. One of the first examples of full-scale FWS CWs with emergent vegetation, are those built in 1967 in Lelystad, in the Netherlands [25] and near Keszthely, Hungary [26].

\subsubsection{CWs with Floating Mats of Emergent Macrophytes}

Some emergent macrophytes are capable of forming floating mats, even though their individual plants are not capable of such an existence. Under field conditions, the floating islands of emergent macrophytes can naturally occur as a consequence of bottom disturbance [27]. Floating mats are a common phenomenon in wetlands throughout the world, both in temperate [28] and (sub)tropical regions [29]. The floating wetlands (called "plavs"), were first described by Pallis in 1915 from the Danube delta in Romania [30].

Buoyancy in natural systems is supported by the composition of a wetland plant biomass, which contains a large amount of air space (aerenchyma) that makes the biomass less dense than water [31]. Buoyancy can also be promoted by the provision of suspended cables over the water surface, from where the roots of plants that tend to form floating mats can cover the whole surface [32]. Other materials used in constructed floating wetlands (Figure 6) are, for example, Styrofoam, coconut-peat strings or bamboo [33,34]. 


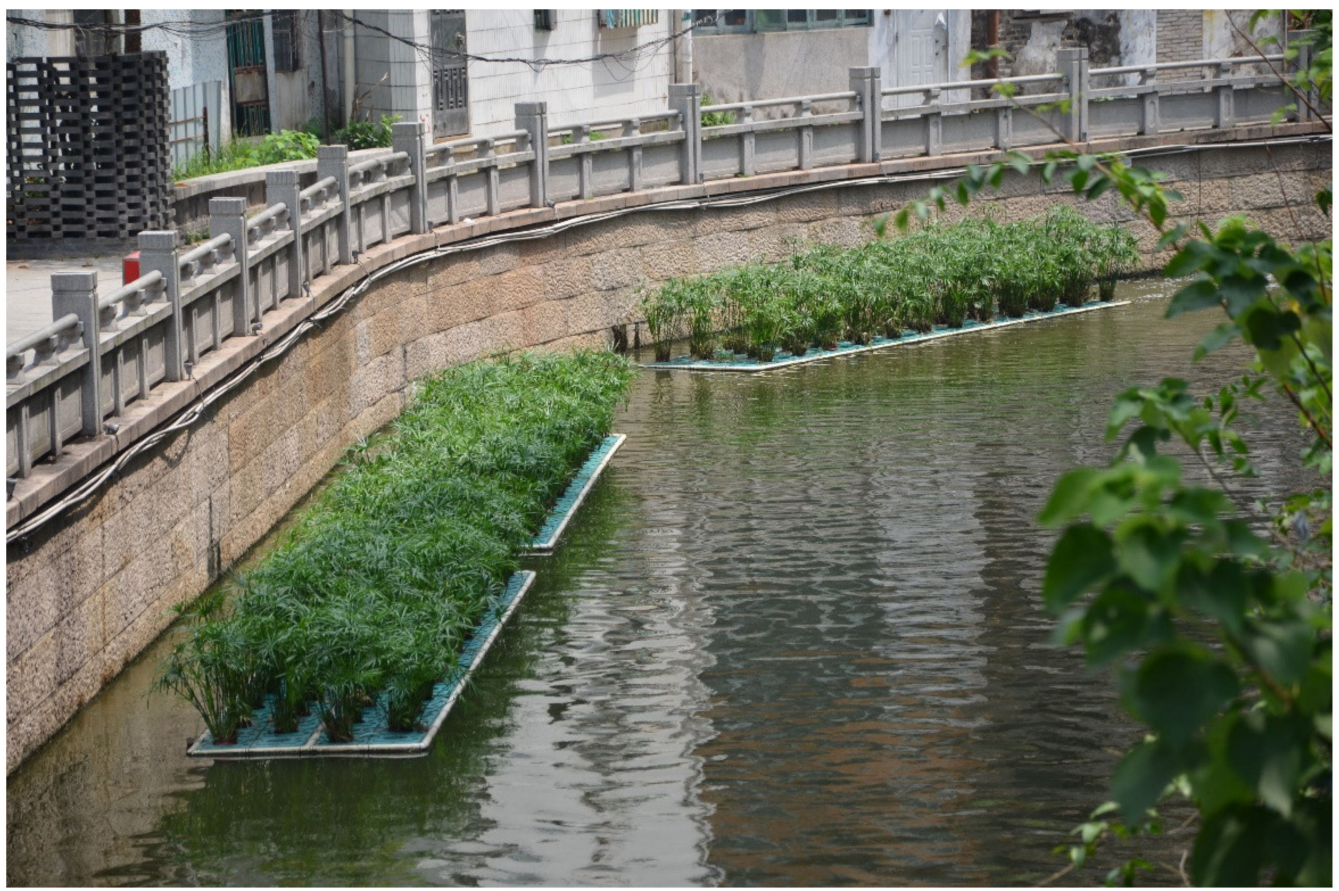

Figure 6. Floating constructed wetland planted with Cyperus alternifolius. Ningbo, China. Photo Jan Vymazal.

\subsubsection{CWs with Trees}

Constructed wetlands with trees are seldom used for wastewater treatment; however, there are some fine examples of such treatment wetlands. The tree species that were used in constructed wetlands are Taxodium distichum (bald cypress) (Figure 1), Melaleuca quinquenervia (paper bark tea tree) or mangroves, which can be used to treat saline (waste)waters (Figure 7 ) or $[35,36]$.

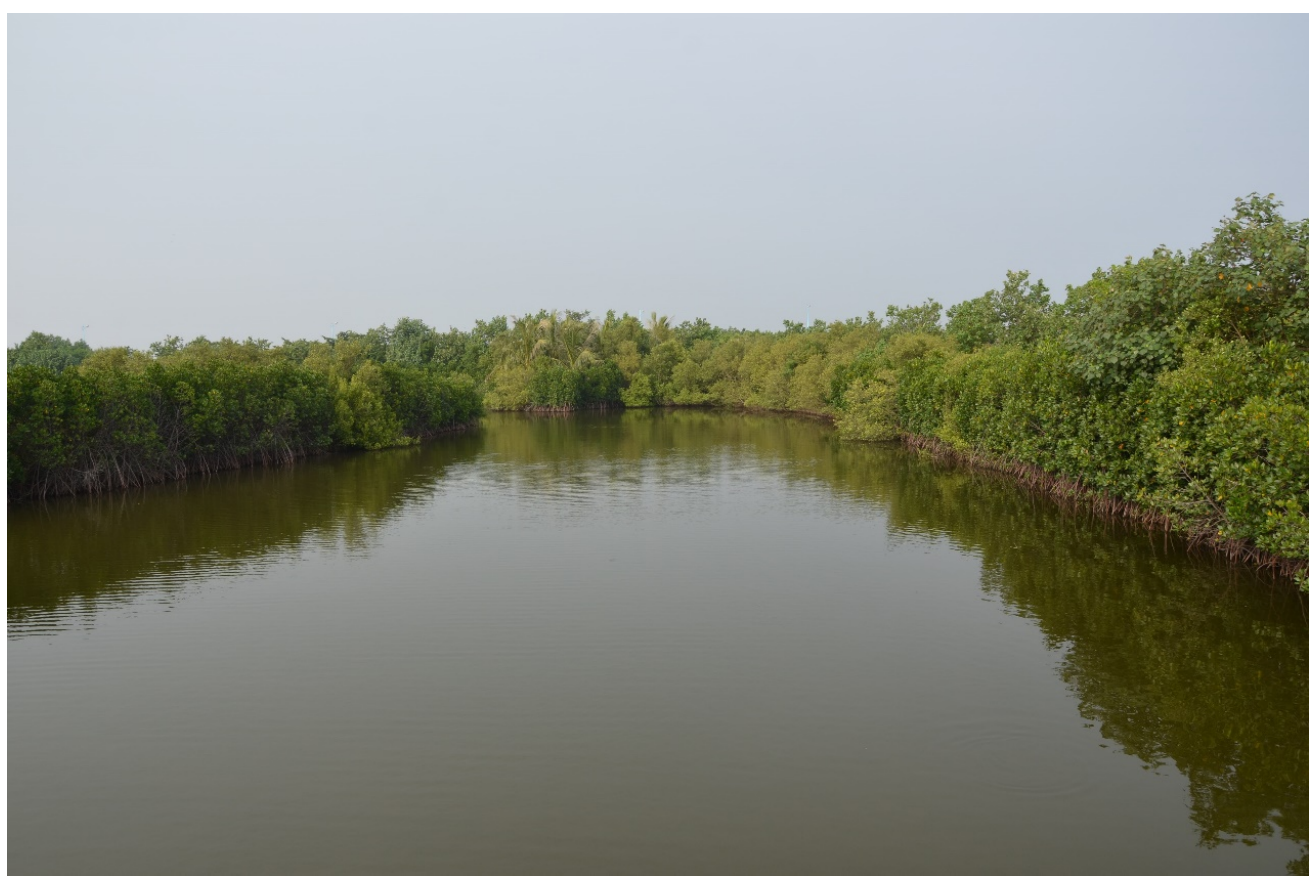

Figure 7. Dapeng Bay, Taiwan: surface flow constructed wetland with mangroves (Kandelia candel) for the treatment of mariculture wastewater. Photo Jan Vymazal. 


\subsection{Subsurface Flow Constructed Wetlands}

Constructed wetlands with a subsurface flow can be classified according to the direction of the flow into horizontal (HF CWs) and vertical (VF CWs). The HF CWs are continuously fed, while VF CWs are fed intermittently. The feeding mode creates different redox conditions in the filtration media being anoxic/anaerobic in HF CWs and aerobic in VF CWs. A special category of subsurface CWs is "zero-discharge" CW.

\subsubsection{Horizontal Flow Constructed Wetlands}

In HF CWs, mechanically pretreated wastewater slowly flows under the surface of the filtration bed filled with porous material planted with emergent macrophytes (Figures 8 and 9). During this passage through the filtration material, the wastewater comes into contact with a network of aerobic, anoxic and anaerobic zones. The aerobic zones are restricted to narrow zones adjacent to the roots and rhizomes that leak oxygen into the substrate $[8,37]$. The filtration bed is sealed from the surrounding area by an impermeable layer; in most cases, a plastic liner to prevent leakage to the groundwater. The water level in the filtration bed is maintained in the outflow sump using swiveling elbows (Figure 10) or flexible hoses, or plastic pipes that can be held in position by a chain (Figure 10).

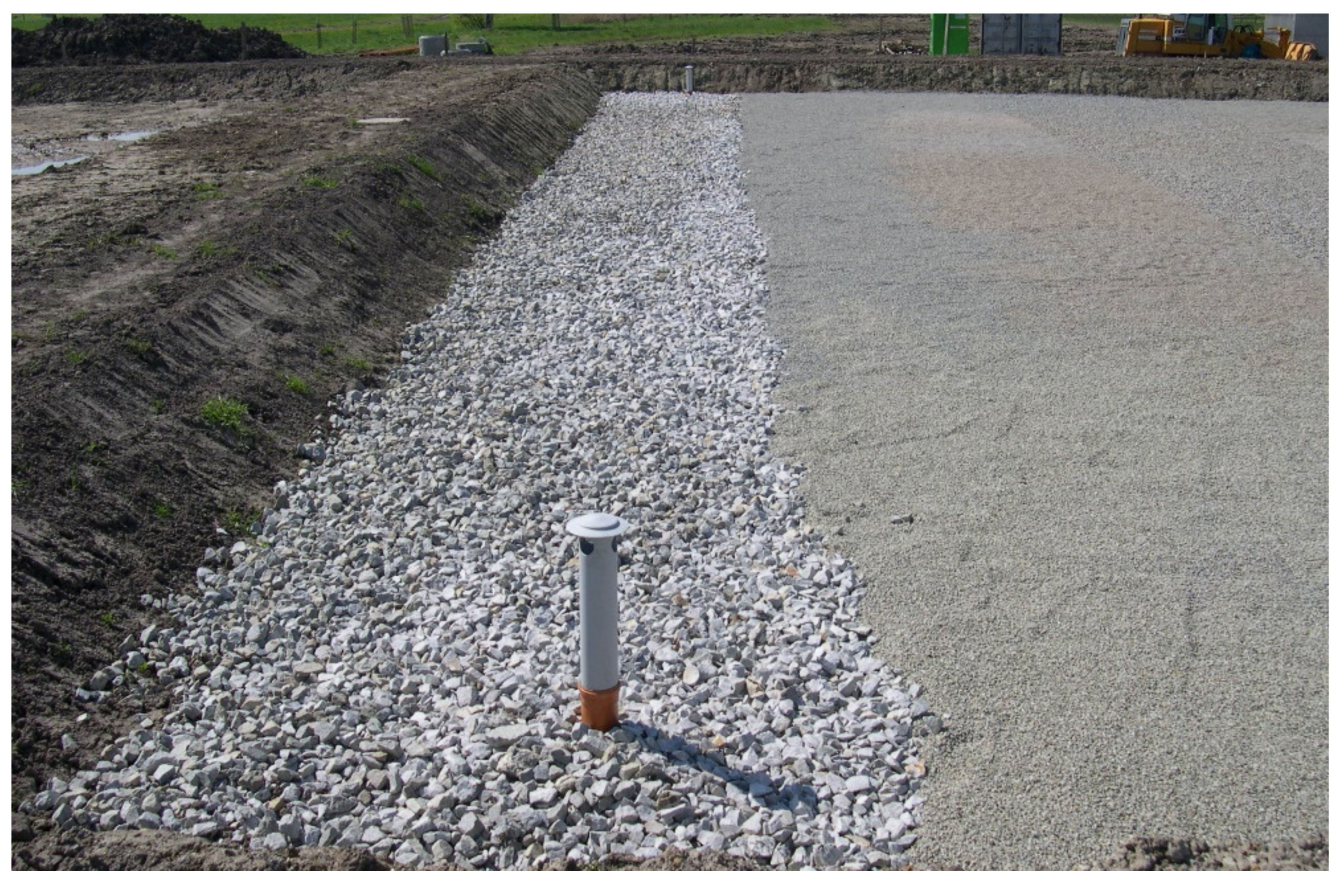

Figure 8. Distribution zone filled with large stones and the filtration bed filled with crushed rocks (4-8 mm) before planting. HF CW Čejkovice, Czech Republic. Photo Jan Vymazal. 


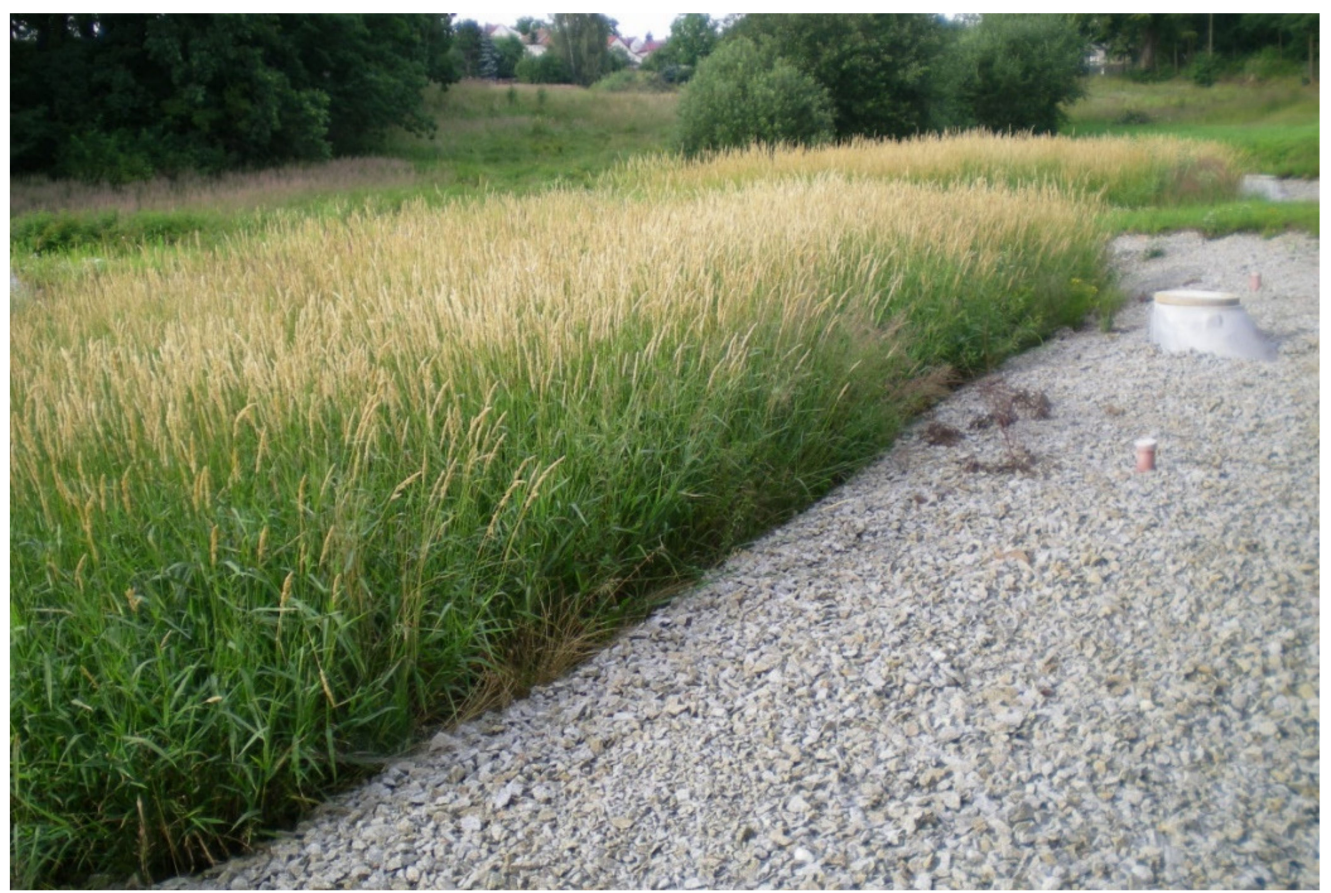

Figure 9. Constructed wetland with a horizontal subsurface flow. Roseč, Czech Republic. Photo Jan Vymazal.
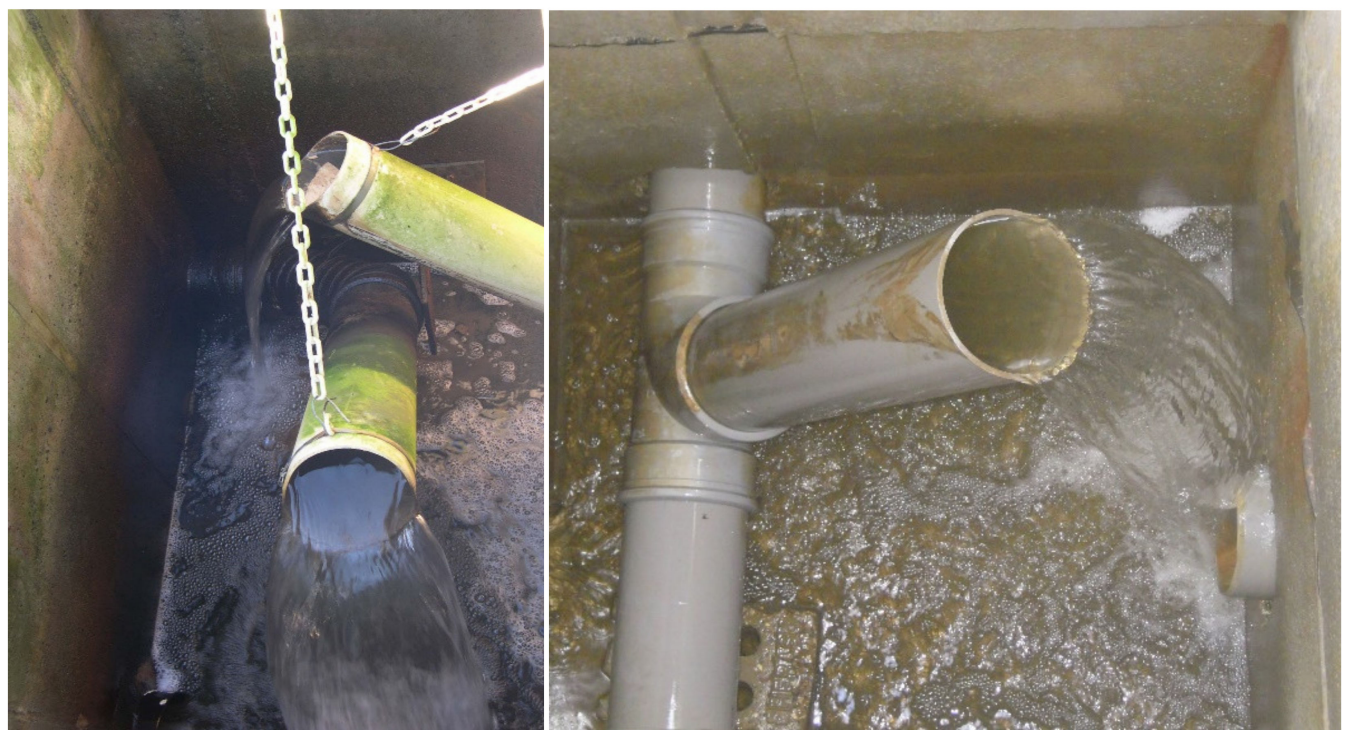

Figure 10. Water level maintenance. Left: outflow pipes hanging on a chain at CW Waikeria, New Zealand. Right: swiveling elbow at CW Bouvron, France. Photo Jan Vymazal.

The early experimental HF CWs in Germany, during the 1960s and early 1970s, were filled with coarse sand [38], which was replaced in the late 1970s and early 1980s with soil [39]. However, the soil substrate did not achieve and maintain the necessary hydraulic conductivity and quickly became clogged [40]. The unsuitability of the soil as a filtration material was confirmed in Denmark in the mid-1980s and, following the research conducted in the United Kingdom, proved that gravel was the most suitable filtration medium [41,42]. At present, most constructed wetlands either use washed gravel or crushed rock with a fraction size between 5 and $20 \mathrm{~mm}$, depending on the country.

The macrophytes growing in constructed wetlands help to create suitable conditions for pollution removal. Their role is rather indirect, such as the (1) insulation of the surface 
during periods of cold weather; the (2) provision of substrates for attached bacteria and the (3) release of the root exudates that can possess antimicrobial properties. The direct role is the sequestration of nutrients from the wastewater in the (aboveground) biomass that can be removed via harvesting [43]. Worldwide, the most frequently used macrophyte is Phragmites australis (Common reed), but many other species, such as Typha spp. (cattails), Phalaris arundinacea (Reed canarygrass, Figure 8), Scirpus (Schoenoplectus) spp. (Bulrush) and Iris pseudacorus (Yellow flag), are used in HF CWs [9].

HF CWs provide a high and steady removal of organics and suspended solids. Organics are degraded by both anaerobic and aerobic microorganisms, but aerobic degradation is mostly restricted to narrow zones adjacent to the roots and rhizomes, in which oxygen can be released [44,45]. Due to the predominant anoxic/anaerobic conditions in the filtration bed, HF CWs provide suitable conditions for denitrification. On the other hand, due to a lack of oxygen, nitrification is very limited and so is volatilization as there is no free water surface. Nitrogen removal through plant uptake and subsequent harvesting is limited and can reach the same values as in natural wetlands, i.e., about $30-60 \mathrm{~g} \mathrm{~N} / \mathrm{m}^{2}$ on an annual basis for large macrophytes, such as P. australis or T. latifolia [46]. Phosphorus removal is usually low, provided that the common filtration materials, such as gravel or crushed rock, are used [47]. However, the removal of phosphorus can be enhanced by the use of materials with a high sorption capacity, such as steel slags, shell sand or expanded clay materials $[48,49]$. In such situations, it necessary to keep in mind that the sorption capacity will be exhausted, and the filter material will have to be replaced in order to keep the high removal. The removal of phosphorus by plant harvesting is limited and usually amounts to $2-5 \mathrm{~g} \mathrm{P} \mathrm{m}^{-2}$ on an annual basis [46].

Horizontal flow constructed wetlands capital costs are higher than those for the surface flow CWs, due to the costs of bed sealing and costs of filtration material, including transportation. The operation and maintenance costs are very low and are derived from the maintenance of pretreatment units. The area required for the filtration beds of HF CWs usually ranges between 5 and $6 \mathrm{~m}^{2}$ per population equivalent [50-52].

\subsubsection{Vertical Flow Constructed Wetlands}

Vertical flow constructed wetlands generally consist of a bed of porous material, through which the water moves in a vertical direction. In general, this group of CWs incorporates various hydrologic characteristics. There are three arrangements of vertical subsurface flow constructed wetlands: down flow, up flow and fill and drain [11].

The most common type of vertical flow CWs is the free-drainage down flow unit, in which the outlet is open at the base of the filter bed. The wastewater is intermittently delivered to the surface of the filtration bed in batches. Each new batch is brought, only after the water from the previous batch has percolated through the filter. This allows for air diffusion in the empty bed and, thus, the filtration bed is predominantly aerobic. Wastewater is spread across the filter surface by a network of pipes (Figure 11) with multiple diffusers, to evenly distribute the wastewater to avoid short circuiting. Influent distribution pipes can be positioned on or above the surface of the filtration bed or, mostly in cold climates, can be buried within the coarse material or under the layer of insulating mulch [11]. This concept, developed as early as the mid-1960s by dr. Seidel in Germany, was used to oxidize the anaerobic outflow from a septic tank [53]. 


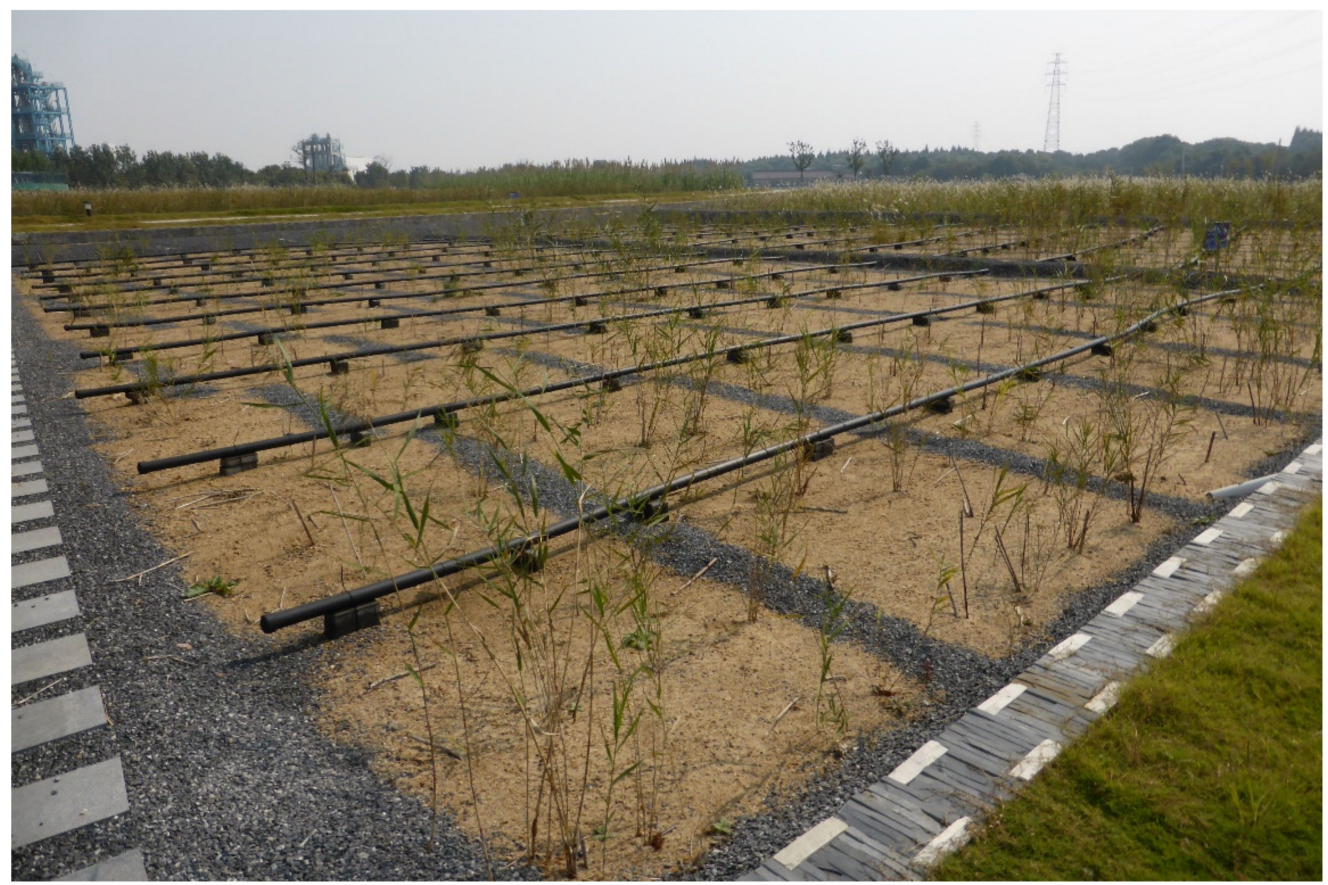

Figure 11. Wastewater distribution pipes at Changshu Advanced Materials Industrial Park VF CW, Suzhou, Jiangsu Province, PR China. Photo Jan Vymazal.

The most common filtration material in down flow CWs is sand. Coarse gravel or stones are used in the drainage layer, where perforated drainage pipes are laid. The most frequently used macrophyte in this type of constructed wetland, especially in Europe, is P. australis (Figure 12). In Asia, various species, such Arundo donax (giant cane), Miscanthus saccharoflorus (Amur silvergrass), Cyperus alternifolius (umbrella papyrus), Thalia dealbata (powdery alligator-flag), Vetiveria zizanoides (vetiver grass) or Canna indica (Indian shot) are used.

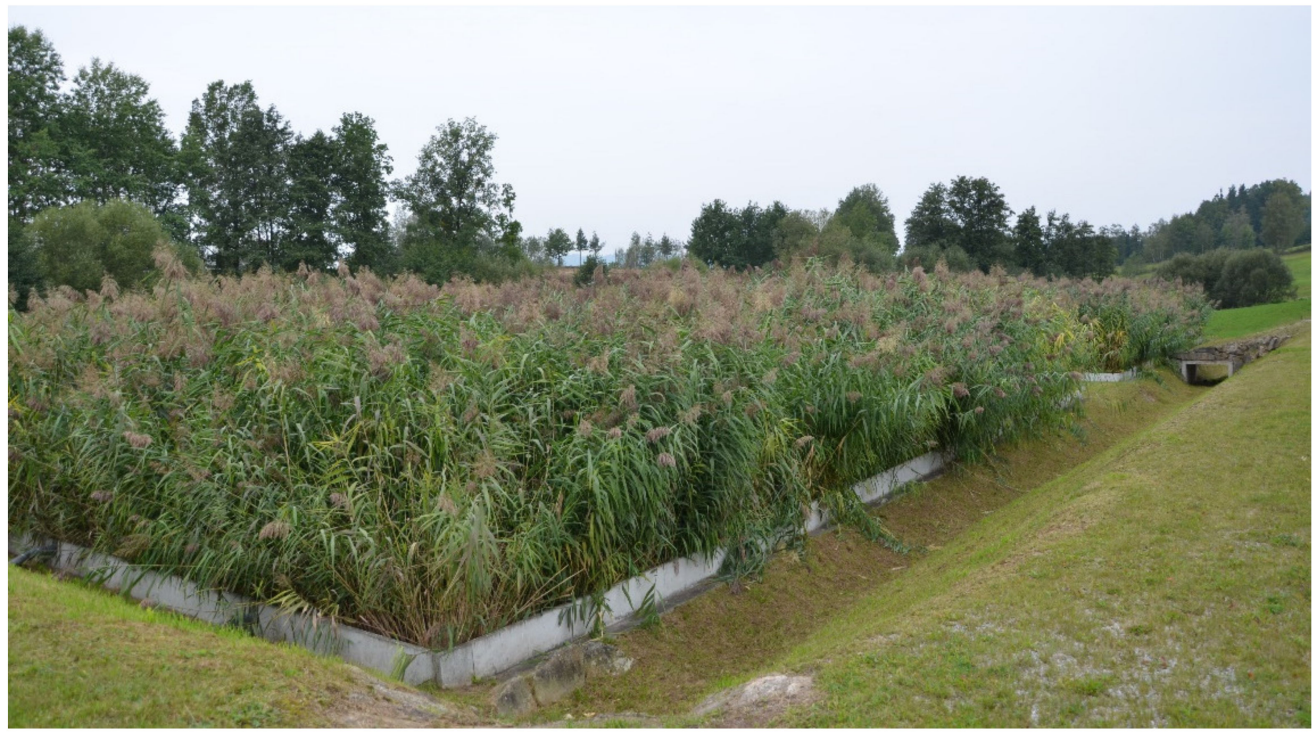

Figure 12. Down flow vertical constructed wetlands planted with Phragmites australis. Oberwindhag, Austria. Photo: Jan Vymazal.

Treatment efficiency is high for organics, suspended solids and ammonia, due to the aerobic conditions in the filter bed, and thus results in effective nitrification. As a 
result of the predominantly aerobic conditions, the down flow vertical CWs do not achieve denitrification. The removal of phosphorus is limited but, similar to the horizontal flow CWS, the removal can be enhanced by filtration material with a high sorption capacity [13].

The surface area required for free drain down flow CWs is smaller than for HF CWs, and it is usually set at $4 \mathrm{~m}^{2}$ per population equivalent [52,54]. In France, down flow VFs are used to treat raw sewage in a two-step VF system, sometimes called the "French system". In the first stage, sludge treatment, the partial removal of organics and nitrification occur. In the second stage, the further removal of organics and nitrification occur. The system is designed with an area of $1.2 \mathrm{~m}^{2}$ per PE for the first stage, and $0.8 \mathrm{~m}^{2}$ per PE for the second stage [55].

The second standard type of system with a vertical subsurface flow is the up flow. In this system, the wastewater is distributed to the bottom of the filter and moves upwards to the filtration bed surface. The outflow can be below or above the bed surface. The up flow vertical constructed wetlands were introduced in the 1980s in Brazil as "filtering soil" (Figure 13). This system is used much less frequently, compared to down flow systems and, in general, provides the same treatment conditions as horizontal flow CWs, due to the saturation of the filtration bed.

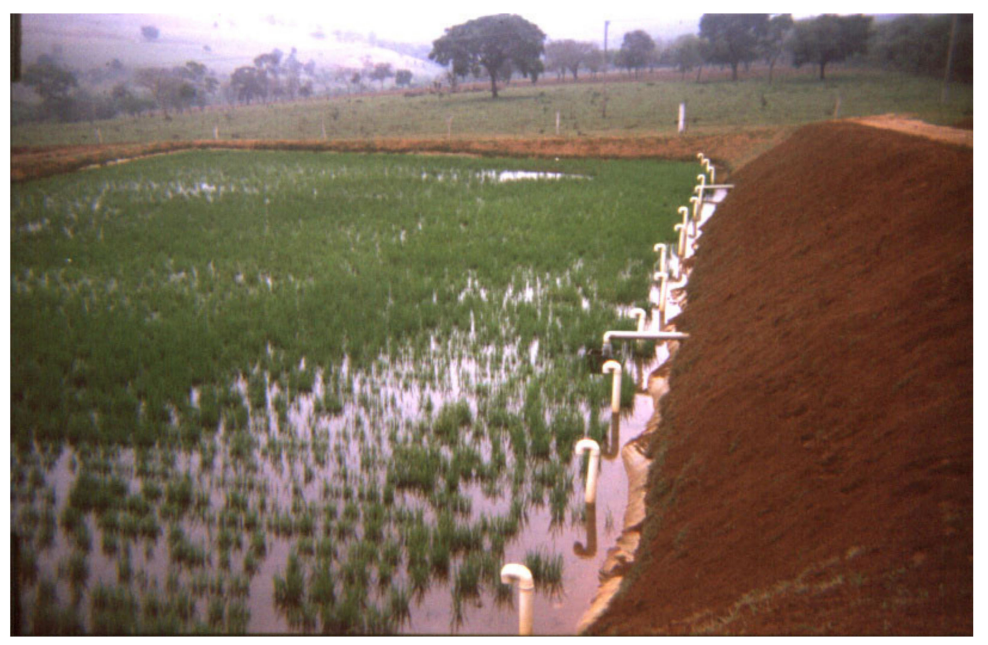

Figure 13. Vertical up flow constructed wetlands planted with rice (Oryza sativa) called "filtering soil", in Piracicaba, Brazil. Photo Jan Vymazal.

The third type of vertical CW is the system called "fill and drain". The flow typically alternates between an upward and downward flow. The media in these systems has an intermittent saturation level, as it alternates between being saturated and unsaturated as a result of the filling and draining sequences [11]. Due to the alternating aerobic and anaerobic conditions, this system has the potential to remove both ammonia and nitrate [56]. The fill and drain system is also called the "reciprocating" or "tidal flow".

\subsection{Zero-Discharge Constructed Wetlands}

The zero-discharge constructed wetland (Figure 14) was developed in Denmark in the late 1990s. The function of the system is based on the fact that, during the growing season, the willow evapotranspiration exceeds the wastewater inflow and precipitation [57]. During the winter period without the evapotranspiration, the filtration bed is filled with wastewater and precipitation; however, during the period of evapotranspiration, the water level in the bed decreases. For a single household in Denmark (Figure 13), the area needed typically varies between 150 and $300 \mathrm{~m}^{2}$. One third of the willow stems is harvested every year to keep the willows in a young and healthy state with high transpiration rates [58]. 


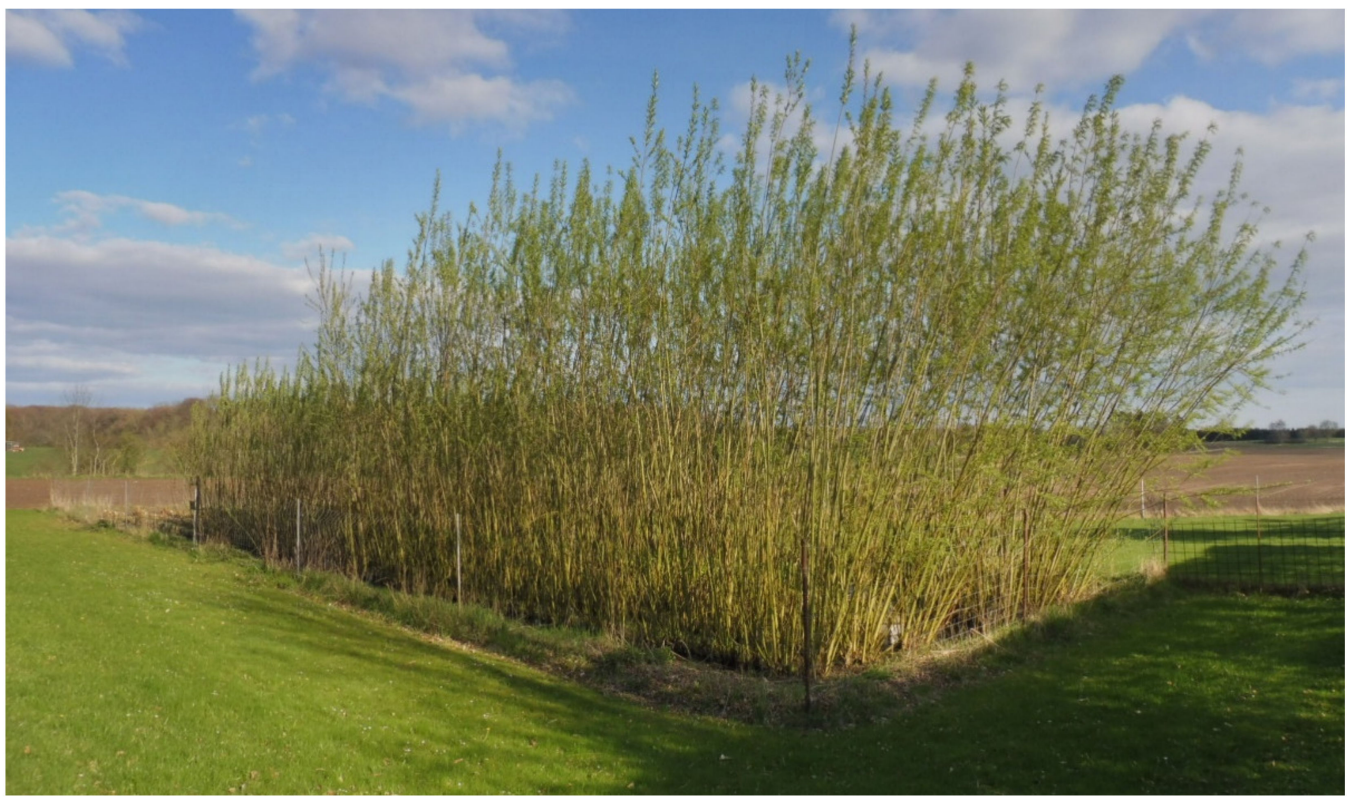

Figure 14. Zero discharge constructed wetlands planted with Salix viminalis (basket willow). Borup, Denmark. Photo Jan Vymazal.

\subsection{Hybrid Constructed Wetlands}

Various types of constructed wetlands can be combined to complement each other, in order to enhance treatment efficiency, especially for nitrogen. Hybrid constructed wetlands were first introduced in the 1960s in Germany [53]. The original design consisted of several parallel down flow VF CWs (called "filtration beds"), followed by two stages of HF CWs (called "eliminations beds"). In the first VF beds, nitrification was achieved while in the HF stage denitrification took place. Since then, various types of constructed wetlands have been combined [59].

\section{Historical Development of Constructed Wetlands as Treatment Technology for Wastewaters}

\subsection{The Early Stages of Constructed Wetland Treatment Technology Development}

Wallace and Knight [60] mentioned that the first documented engineered treatment wetland system was patented as early as 1901 [61]. The treatment system was a typical vertical flow CW; however, the spread of this technology is not documented. It has taken until the early 1950s for the constructed wetland treatment technology to be revived in Germany, by K. Seidel [62-64]. During the early 1960s, Seidel carried out experiments using macrophytes to improve inefficient rural treatment systems (septic tanks and Imhoff tanks). She used highly permeable substrates in modulated basins planted with various macrophytes. The first stage was vertical and aerobic to improve the oxygenation of the septic effluent; the second stage was horizontal [53]. Further cooperation with R. Kickuth in the mid-1960s, resulted in a HF CW commonly known as the "Root Zone Method". The filtration bed was filled with a heavy soil containing clay, and planted with P. australis [65]. However, the first full-scale HF CW was put in operation in 1974 in Liebenburg-Othfresen, to treat municipal wastewater.

Despite the fact that most research studies on constructed treatment wetlands, in the 1960s, were aimed at subsurface systems, the full-scale surface (free water surface) constructed wetlands were built in Lelystad, Netherlands [66,67] and in Keszthely, Hungary [68]. On the other hand, in North America, efforts were made in the 1960s to explore the potential of surface flow CWs, both natural and constructed. During the late 1960s, Odum [69] evaluated the use of coastal lagoons for recycling municipal wastewater in North Carolina. During the 1960s, the first experiments with floating plants, especially with Eichhornia crassipes (water hyacinth), were carried out. The experiments were restricted to 
small mesocosms and were performed in locations in which this plant occurs naturally, such as southeast Asia and southern parts of the United States [70,71].

During the 1970s, the research on constructed wetlands for wastewater treatment in Europe was mostly restricted to the Root Zone Method, and mostly only in Germany. In the United States, the research was focused on surface flow constructed wetlands, but subsurface flow technology was also explored. The surface flow large-scale installations included, for example, constructed wetlands for refinery wastewaters in North Dakota [72] or municipal wastewaters in the cold climate in Michigan [73]. During the 1970s, very intensive research was also carried out with the focus on water hyacinth-based constructed wetlands, especially in the Southern States of the United States [74-77]. The first experimental HF mesocosms were built in 1972, and the pilot scale HF CW was built in 1974, in Seymour, Wisconsin [78]. The system could be operated with the water level above as well as below the surface, although the subsurface flow was the preferred option. On the West Coast, the California sub-licensee for the Max Planck Institute (MPI) system, developed by Seidel in Germany, built a hybrid VF-HF CW in Laguna Niguel [79]. Moreover, two large national conferences were organized in the United States with the focus on the use of wetlands for wastewater treatment $[80,81]$.

In Australia, the potential use of aquatic and wetland macrophytes for wastewater treatment was evaluated by Mitchell, during the mid-1970s [82].

\subsection{The Rapid Growth of Constructed Wetlands Technology across the World}

The 1980s and 1990s can be regarded as the periods that witnessed the rapid extension of the constructed wetlands for wastewater treatment across the world. While until the beginning of the 1980s the technology spread slowly and mostly on a personal exchange of the experience during the late 1980s and during the 1990s, many international conferences with a special focus on this technology were organized in Europe, Asia, Australia and both North and South America. These conferences were mostly organized under the umbrella of the International Water Association (in the 1990s, under the names International Association on Water Pollution Research and Control and International Association on Water Quality).

During the mid-1980s, the international cooperation and exchange on constructed wetland technology in Europe accelerated extensively. In October 1986, the cooperation among ten European countries resulted in the decision to form a European coordinating group, with the two major objectives being the production of design and operation guidelines and to organize a conference in 1990 to bring together experts from around the world [83]. Meanwhile, in the Unites States, two major international conferences on the use of plants and constructed wetlands for wastewater treatment were organized in Orlando, Florida (1986) [84] and in Tallahassee, Tennessee (1988) [85]. These conferences, together with the conference organized in Cambridge in 1990 by the European coordinating group [86], represented a major breakthrough in constructed wetland technology extension around the world.

In Europe during the 1980s, horizontal subsurface flows were the major focus, especially in Germany [87], Denmark [88], Austria [89] and the United Kingdom [90]. In 1983, the soil-based Kickuth-type HF CWs were introduced to Denmark and, shortly after that, about 80 full-scale constructed wetlands were built, mostly for municipal sewage. The evaluation of the performance of these systems revealed that the area originally proposed by Kickuth $\left(\mathrm{m}^{2} / \mathrm{PE}\right)$ was not enough to provide sufficient treatment, and an area of about $5 \mathrm{~m}^{2} / \mathrm{PE}$ was suggested [88]. Moreover, in 1983, a large pilot scale HF CW was built in Mannersdorf near Vienna, Austria. The system was monitored for seven years and the results were summarized by Haberl and Perfler [91]. After a visit to Germany from engineers from U.K. water companies, two full-scale HF constructed wetlands were built (Acle and St. Pauls Walden) in 1985 in UK, and, in the following year, another 21 full-scale systems, such as Freethorpe (Figure 15), were built [90]. 


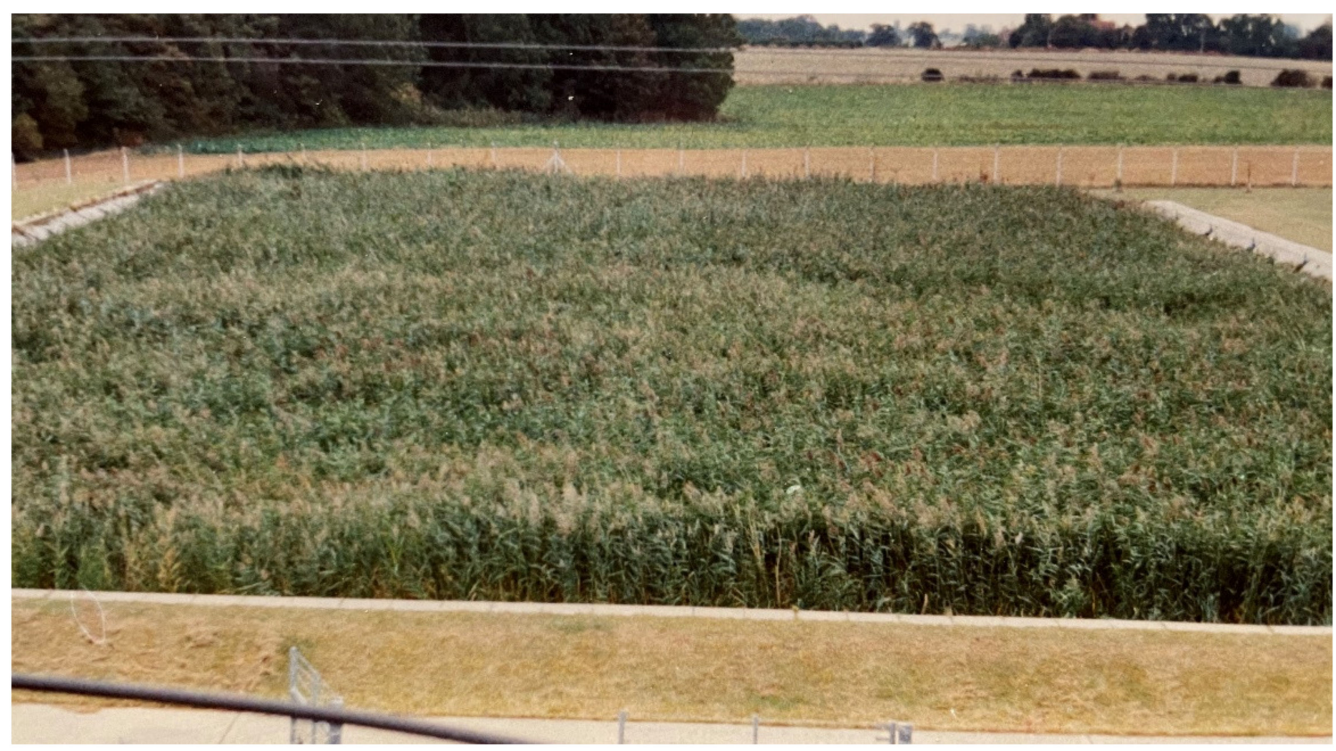

Figure 15. Horizontal subsurface flow CW, Freethorpe, United Kingdom, for 900 PE. The early CWs were built as a single bed. Photo Jan Vymazal.

The systems were very intensively monitored, and the major outcome of this research was the recommendation to replace soil with gravel, 5-10 $\mathrm{mm}$ in size [92,93]. At the end of the 1980s, the hybrid constructed wetlands of Seidel's configuration (VF-HF) were installed in France [94] and the United Kingdom [95]. At the end of the 1980s, the national guidelines on the design and operation of constructed wetlands for wastewater treatment were issued by ATV in Germany [96], and, shortly after that, the European guidelines were published [97].

In North America, surface flow constructed wetlands were built quite regularly, during the 1980s. Many of these systems served as tertiary treatment units for municipal sewage, and the surface area was usually quite large. Examples of such systems are Incline Village, Nevada (173.28 ha), Ironbridge, Florida (494 ha, Figure 16) or Arcata, California (15.18 ha) [12,98]. In addition to the use of surface flow CWs for municipal sewage, other types of wastewaters were treated in the constructed wetlands, such as urban runoff [99], acid mine drainage $[100,101]$ or livestock feedlot wastewaters [102]. The costly operation and maintenance of water hyacinth-based constructed wetlands, mainly connected with constant harvesting and the disposal of the biomass, caused the gradual cessation of the use of these systems [103].
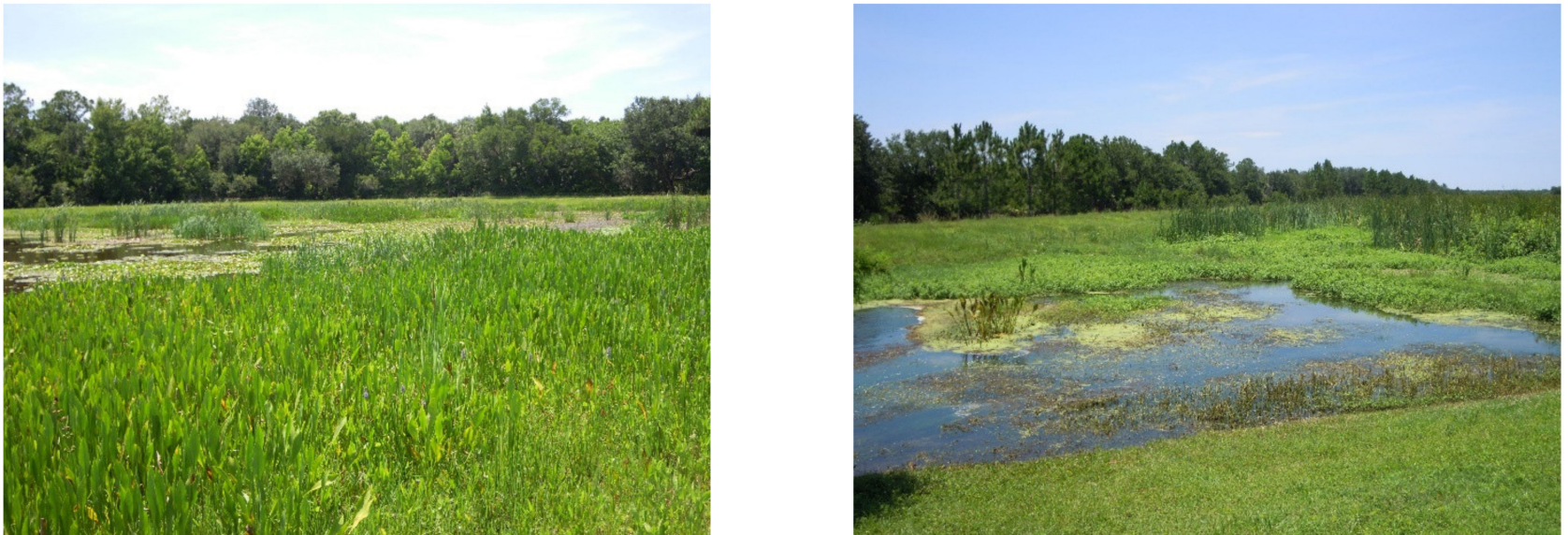

Figure 16. Surface flow CW at Ironbridge. Tertiary treatment for the city of Orlando, Florida. Photo Jan Vymazal. 
The CW consists of 17 cells with a total area of $4.92 \mathrm{~km}^{2}$. The figure features two of those cells (see also Figure 3).

In North America, subsurface technology was developed slowly, compared to its development in Europe. However, several full-scale installations were put in operation for municipal sewage in California, Louisiana, Alabama, Tennessee and Kentucky [12,104-106], or the paper mill effluent [107]. In the United States, the experience with the design and operation of constructed wetlands was summarized in the manual issued by the U.S. Environmental Protection Agency [108].

The subsurface technology was also developed in Australia during the 1980s, and pilot HF CWs were built to treat piggery waste and abattoir wastewater $[109,110]$. Pilot scale HF CW experiments with various macrophytes were carried out at the University of Western Sydney at Hawkesbury (Figure 17), where numerous studies were conducted [111]. In Africa, the constructed wetlands have been used since the mid-1980s, especially in South Africa. The constructed wetlands were designed to treat various types of wastewater, including raw and secondary sewage, stormwater runoff and a variety of industrial and mine drainage waters. In these systems, surface flow as well as subsurface flow systems were used [112]. In South America, the constructed wetlands were applied only in Brazil [113]. Research focused on water hyacinth-based systems in combination with up flow vertical CWs, called "filtering soil" (Figure 13). There are no records of full-scale constructed wetlands in Asia during the 1980s.

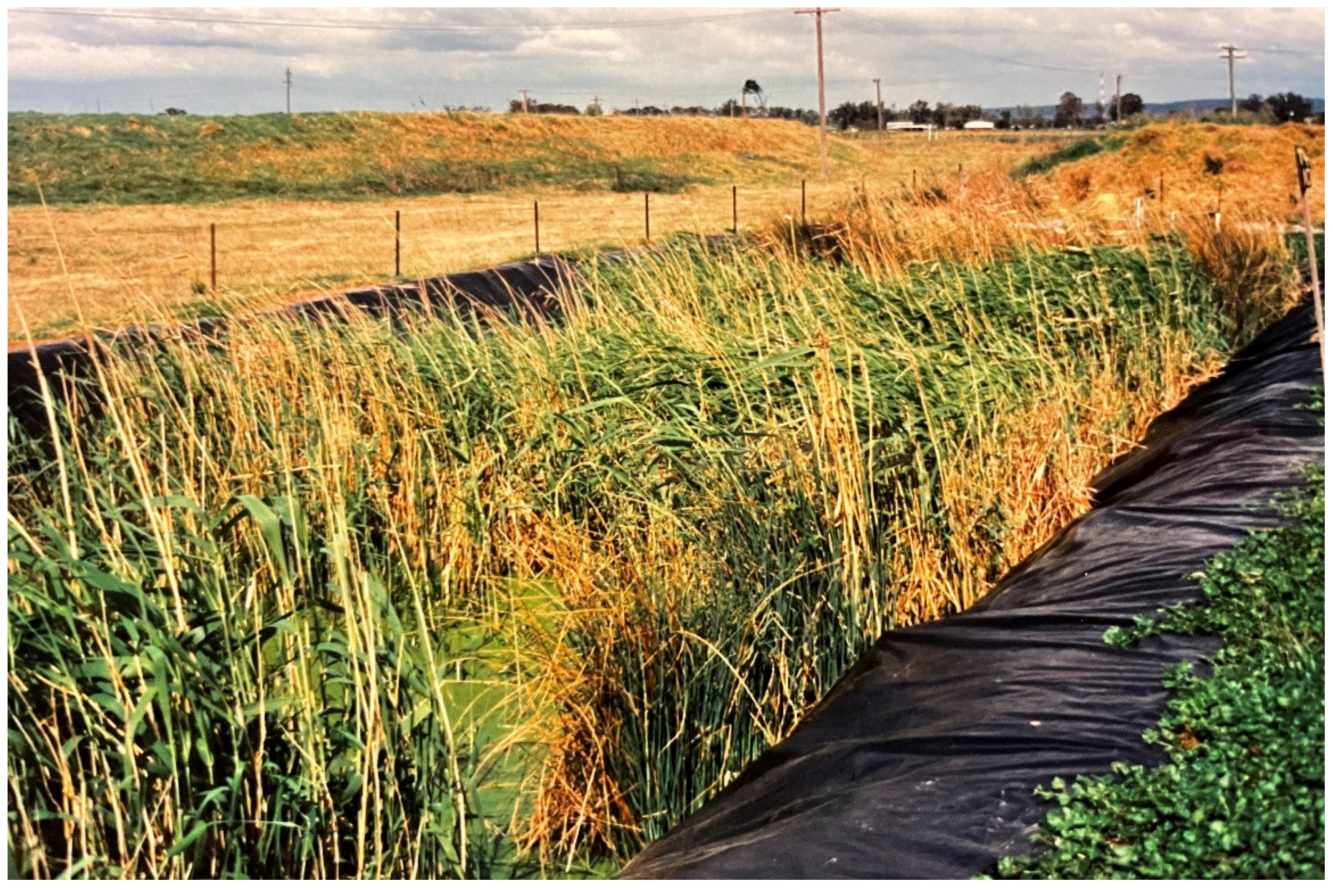

Figure 17. Experimental HF CW at the University of Western Australia, Hawkesbury. Photo Jan Vymazal.

During the last decade of the 20th century, the constructed wetland technology extended to all continents and all types of constructed wetlands were used. During the 1990s, the technology started in several Asian countries, namely China, India and Nepal. In China, the first full-scale constructed wetland was put in operation in July 1990 at the Longgang Shenzen Special Economic Zone [114]. The constructed wetlands consisted of three stages of HF units with a total surface area of $4589 \mathrm{~m}^{2}$, and a surface flow cell with a surface area of $1710 \mathrm{~m}^{2}$. Other hybrid CWs were used to treat pig raising farm wastewater or industrial wastewater [115]. In India, mostly HF constructed wetlands planted with Phragmites karka were built to treat municipal sewage [116]. In Nepal, in the 1990s, constructed wetlands drew a lot of attention because of the low costs for the operation and maintenance of them; 
however, most systems suffered from a lack of maintenance. The hybrid system in Dhulikel was probably the first constructed wetland built to treat hospital wastewater [117].

The rapid growth of constructed wetland installations, as well as the increased knowledge on processes occurring in constructed wetlands during the treatment of various types of wastewater, resulted in the release of national guidelines in many countries, such as in Austria, [118], Denmark [119], New Zealand [120] and Canada [121], during the late 1990s.

\subsection{Constructed Wetlands for Wastewater Treatment in the 21st Century}

Constructed wetlands became a "certified" method for wastewater treatment, in many countries across the world in the 21st century. In some countries, such as China, the number of constructed wetlands exceeds one hundred thousand and it is still growing (Figure 18). There is also a growing number of constructed wetlands in South America, especially in Colombia, Argentina and Chile. Unfortunately, the technology has not spread significantly in Africa, where there is great potential for this technology.
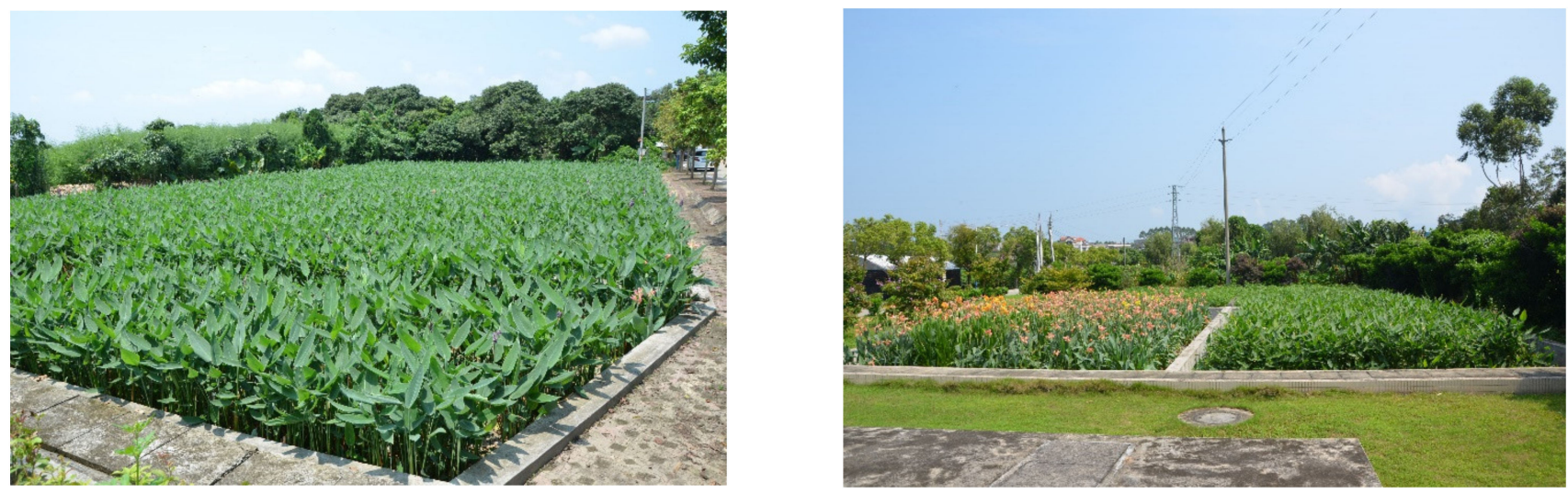

Figure 18. Constructed wetlands with horizontal subsurface flow, planted with Thalia dealbata (left) and Canna indica and Thalia dealbata (right) in Quangdong Province near Guangzhou. Photo Jan Vymazal.

At the beginning of the 21st century, research on the wastewater treatment in constructed wetlands focused on the various design and operation aspects that can lead to the enhanced removal of pollutants [122,123]:

- $\quad$ operation strategies (such as aeration, microbial fuel cells and bioaugmentation);

- $\quad$ supply of electron donors to enhance the removal of selected inorganic anions;

- $\quad$ selection of filter materials for higher sorption capacity and microbial biofilm establishment;

- determination of functions of various bacteria groups on pollution removal;

- selection of macrophytes for enhanced removal of pollutants;

- $\quad$ effect of constructed wetlands on greenhouse gas emissions;

- efficacy of constructed wetlands to remove pharmaceuticals and personal care products.

Constructed wetlands for wastewater treatment are also gaining more attention in relation to sustainable water management in urban settlements, as part of the circular economy and "sponge" cities. Masi et al. [124] pointed out that constructed wetlands can be effectively used in cities to treat sewage, greywater, stormwater overflows and runoff, and can effectively recycle the water within cities. Constructed wetlands can also be a core part of SUDS (Sustainable Urban Drainage Systems). Moreover, Stefanakis [125] stressed that constructed wetlands for wastewater treatment have a great potential to be successfully integrated in urban and peri-urban areas, and fit well within the new concept of sponge cities and the circular economy. The importance of constructed treatment wetlands within urban circularity through the restoration and maintenance of water cycles, water and 
wastewater treatment, recovery and reuse as well as nutrient recovery and reuse was reported by Atanasova et al. [126].

Unfortunately, most of the research is carried out in small laboratory or greenhouse experiments, with no attempts to include the results of this experiments in a design of full-scale installations. Vymazal [127] pointed out that while, in 1995, $88 \%$ of the papers recorded on the Web of Science database were based on full-scale CWs, in 2017 it was only $26 \%$. It seems that the transfer of the laboratory experiment results to the full-scale constructed wetlands will be the major challenge in coming years.

\section{The Use of Constructed Wetlands for Various Types of Wastewater}

The early use of constructed wetlands was restricted to sewage treatment. The various types of constructed wetlands and their combination enabled the use of CWs for a variety of wastewaters (Tables 1 and 2).

Table 1. The use of constructed wetlands for various types of wastewater.

\begin{tabular}{|c|c|}
\hline Type of (Waste) Water & Examples of Use \\
\hline Sewage & Domestic, municipal, combined sewer overflow \\
\hline Drainage & $\begin{array}{l}\text { Acid/alkaline coal mines, metal ores mines, agricultural } \\
\text { tile drainage }\end{array}$ \\
\hline Feedlots & Livestock, poultry, pigs, milking parlors \\
\hline Aquacultures & Freshwater fish, marine fish, shrimp \\
\hline Food processing & $\begin{array}{l}\text { Dairy, cheese, winery, brewery, distillery, sugar, olive } \\
\text { mills, fish, soft drinks, abattoir, meat processing }\end{array}$ \\
\hline Other industries & $\begin{array}{l}\text { Tannery, textile, electroplating, pulp and paper, glass, } \\
\text { explosives, refineries, oil drilling water, rubber industry }\end{array}$ \\
\hline Runoff waters & $\begin{array}{c}\text { Urban, highway, airport, greenhouses, nurseries, golf } \\
\text { courses, agricultural fields }\end{array}$ \\
\hline Landfill leachate & \\
\hline
\end{tabular}

Table 2. Examples of the first use of macrophytes and/or constructed wetlands for the treatment of different types of pollution. Experimental (laboratory, mesocosms) and Operational (pilot scale, full scale). Modified and updated from Vymazal and Kröpfelová [13].

\begin{tabular}{ccc}
\hline & Experimental & \\
\hline Year & Wastewater & References \\
\hline 1952 & Phenol wastewater & {$[128]$} \\
\hline 1956 & Sewage and dairy wastewater & {$[129]$} \\
\hline 1956 & Livestock wastewater & {$[64]$} \\
\hline 1965 & Sludge dewatering & {$[130]$} \\
\hline 1973 & Textile wastewater & {$[131]$} \\
\hline 1975 & Photographic laboratory wastewater & {$[132]$} \\
\hline 1978 & Acid mine drainage & {$[133]$} \\
\hline 1980 & Electroplating wastewater & {$[134]$} \\
\hline 1980 & Removal of cresol & {$[135]$} \\
\hline 1980 & Piggery effluent & {$[110]$} \\
\hline 1980 & Abattoir wastewater & {$[109]$} \\
\hline 1981 & Heavy metals removal & {$[136]$} \\
\hline 1981 & Tannery wastewater & {$[137]$} \\
\hline
\end{tabular}


Table 2. Cont.

\begin{tabular}{|c|c|c|}
\hline \multicolumn{3}{|c|}{ Experimental } \\
\hline Year & Wastewater & References \\
\hline 1982 & Agricultural drainage effluent & [138] \\
\hline 1982 & Pesticides & [139] \\
\hline 1982 & Sugar refinery wastewater & [140] \\
\hline 1982 & Benzene and its derivatives & [141] \\
\hline 1982 & Rubber industry effluent & [142] \\
\hline 1983 & Pulp/paper mill wastewater & {$[143,144]$} \\
\hline 1985 & Seafood processing wastewater & [145] \\
\hline 1986 & Potato starch industry wastewater & [146] \\
\hline 1986 & Cyanides and chlorophenols & [147] \\
\hline 1987 & Meat processing wastewater & [148] \\
\hline 1988 & Landfill leachate & {$[149,150]$} \\
\hline 1989 & Chicken farm wastewater & [151] \\
\hline 1991 & Fish aquaculture & [152] \\
\hline 1991 & Phenanthrene & [153] \\
\hline 1994 & Hydrocarbons & [154] \\
\hline 1995 & Lignite pyrolysis wastewater & [155] \\
\hline 1997 & Winery wastewater & [156] \\
\hline 1998 & Coke plant wastewater & [157] \\
\hline 2000 & Linear alkylbenzensulfonates (LAS) & [158] \\
\hline 2001 & $\begin{array}{l}\text { Steel processing industry } \\
\text { wastewaters }\end{array}$ & [159] \\
\hline 2001 & Brewery wastewater & [160] \\
\hline 2001 & Electric utility wastewater & [161] \\
\hline 2003 & Azo dyes removal & [162] \\
\hline 2004 & Chlorobenzene removal & [163] \\
\hline 2004 & Steel mill effluent & [164] \\
\hline 2006 & $\begin{array}{l}\text { Sugarcane molasse stillage from } \\
\text { ethanol production }\end{array}$ & [165] \\
\hline 2008 & Brine treatment & [166] \\
\hline 2008 & Coffee fruit processing wastewater & [167] \\
\hline 2010 & Saline aquaculture wastewater & [168] \\
\hline 2010 & Brackish shrimp growout system & [169] \\
\hline 2105 & Bauxite residue drains & [170] \\
\hline 2017 & Rice noodles wastewater & [171] \\
\hline 2018 & Glass industry wastewater & [172] \\
\hline 2019 & Batik wastewater & [173] \\
\hline 2020 & Jewelry industry wastewater & [174] \\
\hline
\end{tabular}


Table 2. Cont.

\begin{tabular}{|c|c|c|}
\hline \multicolumn{3}{|c|}{ Operational } \\
\hline Year & Wastewater & References \\
\hline 1967 & Sewage & [66] \\
\hline 1974 & Sludge dewatering & [175] \\
\hline 1975 & Oil refinery wastewater & [176] \\
\hline 1978 & Textile wastewater & [177] \\
\hline 1979 & Fish rearing pond discharge & [178] \\
\hline 1982 & Acid mine drainage & {$[179,180]$} \\
\hline 1983 & Urban stormwater runoff & [99] \\
\hline 1983 & Rubber industry effluent & [142] \\
\hline 1985 & Dairy wastewater & [41] \\
\hline 1986 & Seepage from piled pig muck & [181] \\
\hline 1986 & Ash pond seepage & [182] \\
\hline 1987 & Thermally affected wastewater & [183] \\
\hline 1988 & Livestock wastewater & [102] \\
\hline 1988 & Pulp/paper mill wastewater & [107] \\
\hline 1988 & Pesticides & [184] \\
\hline 1989 & Landfill leachate & [185] \\
\hline 1989 & Airport runoff & [186] \\
\hline 1989 & Reduction of lake eutrophication & [187] \\
\hline 1990 & Lake water & [188] \\
\hline 1991 & Woodwaste leachate & [189] \\
\hline 1992 & Bakery wastewater & [190] \\
\hline 1992 & Channel catfish pond effluent & [191] \\
\hline 1992 & Sugar beet processing wastewater & [192] \\
\hline 1992 & Combined sewer overflow & [193] \\
\hline 1993 & Pesticides in agricultural runoff & [194] \\
\hline 1993 & Highway runoff & [195] \\
\hline 1994 & Abattoir wastewater & [196] \\
\hline 1994 & Airport runoff & [197] \\
\hline 1994 & Poultry wastewater & [198] \\
\hline 1995 & Greenhouse wastewater & [199] \\
\hline 1995 & Nitroaromatic organic compounds & [200] \\
\hline 1995 & Potato processing wastewater & [201] \\
\hline 1996 & Explosives & {$[202,203]$} \\
\hline 1997 & Hydrocarbons & [204] \\
\hline 1997 & Hospital wastewaters & [117] \\
\hline 1998 & Trout farm effluent & [205] \\
\hline 1998 & Golf course runoff & [206] \\
\hline 1998 & Nylon and ethylene polymers & [207] \\
\hline 1999 & Molasses-based distillery effluent & [208] \\
\hline 1999 & Winery wastewater & [156] \\
\hline
\end{tabular}


Table 2. Cont.

\begin{tabular}{ccc}
\hline & Operational & \\
\hline Year & Wastewater & References \\
\hline 1999 & Distillery wastewater & {$[208]$} \\
\hline 2000 & Surfactant removal & {$[209]$} \\
\hline 2000 & Subsurface drainage from grazed \\
& dairy pastures & {$[210]$} \\
\hline 2001 & Tannery wastewater & {$[211]$} \\
\hline 2002 & Tool factory wastewater & {$[212]$} \\
\hline 2002 & Pharmaceuticals removal & {$[213]$} \\
\hline 2003 & Olive mill wastewater & {$[214]$} \\
\hline 2004 & Sugar factory effluent & {$[215]$} \\
\hline 2007 & Mountain cheese factory & {$[216]$} \\
\hline 2009 & Flower farm effluent & {$[217]$} \\
\hline 2010 & Brewery wastewater & {$[218]$} \\
\hline 2010 & Brackish shrimp aquaculture & wastewater \\
\hline
\end{tabular}

Constructed wetlands have been used to treat various types of wastewater, since the 1950s. In the beginning, this treatment technology spread slowly, based only on personal contacts. The worldwide distribution of constructed treatment wetlands occurred in the 1990s, primarily due to several large international conferences. Since the beginning of the 21st century, constructed wetlands for wastewater treatment have become a worldwide phenomenon and an accepted technology in many countries around the world. However, in some countries, the treatment performance of constructed wetlands is still underestimated by water authorities and, therefore, the number of installed constructed wetlands is slow.

Until recently, constructed treatment wetlands have mostly been built and considered with the sole purpose of wastewater treatment. However, in addition to the high treatment efficiency, the constructed treatment wetlands have recently been shown to have a great potential in the new sustainable and circular economy in the urban environment. Constructed treatment wetlands can effectively treat, accumulate and recycle water and nutrients for further use, as suggested in the "sponge city" concept.

Funding: This research received no external funding.

Institutional Review Board Statement: Not applicable.

Informed Consent Statement: Not applicable.

Data Availability Statement: Review paper, no original data.

Conflicts of Interest: The author declares no conflict of interest.

\section{References}

1. Mitsch, W.J.; Gosselink, J.G. Wetlands, 3rd ed.; John Wiley and Sons: New York, NY, USA, 2000.

2. Cowardin, L.M.; Carter, V.; Golet, F.C.; LaRoe, E.T. Classification of Wetlands and Deepwater Habitats of the United States. U.S.; FWS/OBS-79/31; Department of the Interior, Fish and Wildlife Service: Washington, DC, USA, 1992.

3. Wentz, W.A. Ecological/environmental perspectives on the use of wetlands in water treatment. In Aquatic Plants for Water Treatment and Resource Recovery; Reddy, K.R., Smith, W.H., Eds.; Magnolia Publishing: Orlando, FL, USA, 1987 ; pp. 17-25.

4. Kadlec, R.H.; Tilton, D.L. The use of freshwater wetlands as a tertiary wastewater treatment alternative. CRC Crit. Rev. Environ. Control 1979, 9, 185-212. [CrossRef]

5. $\quad$ Ewel, K.C.; Harwell, M.A.; Kelly, J.R.; Grover, H.D.; Bedford, B.L. Evaluation of the Use of Natural Ecosystems for Wastewater Treatment. In Ecosystem Research Center Report No. 15; Cornell University: Ithaca, NY, USA, 1982. 
6. Olson, R.K. (Ed.) Created and Natural Wetlands for Controlling Nonpoint Source Pollution; U.S. EPA Office of Research and Development, Office of Wetlands, Oceans, and Watersheds: Corvallis, OR, USA, 1993.

7. Brix, H. Wastewater treatment in constructed wetlands: System design, removal processes, and treatment performance. In Constructed Wetlands for Water Quality Improvement; CRC Press: Boca Raton, FL, USA, 1993; pp. 9-22.

8. Brix, H. Treatment of wastewater in the rhizosphere of wetland plants-the root zone method. Water Sci. Technol. 1987, 19, 107-118. [CrossRef]

9. Vymazal, J. Plants used in constructed wetlands with horizontal subsurface flow: A review. Hydrobiologia 2011, 674, 133-156. [CrossRef]

10. Vymazal, J. Removal of phosphorus in constructed wetlands with sub-surface flow in the Czech Republic. Water Air Soil Pollut. Focus 2004, 4, 657-670. [CrossRef]

11. Fonder, N.; Headley, T. Systematic classification, nomenclature and reporting for constructed treatment wetlands. In Water and Nutrient Management in Natural and Constructed Wetlands; Vymazal, J., Ed.; Springer Science+Business Media B.V.: Dordrecht, The Netherlands, 2010; pp. 191-219.

12. Kadlec, R.H.; Knight, R.L. Treatment Wetlands; CRC Pess LLC: Boca Raton, FL, USA, 1996.

13. Vymazal, J.; Kröpfelová, L. Wastewater Treatment in Constructed Wetlands with Horizontal Sub-Surface Flow; Springer: Dordrecht, The Netherlands, 2008.

14. Richardson, C.J. Mechanisms controlling phosphorus retention capacity in freshwater wetlands. Science 1985, $228,1424-2427$. [CrossRef]

15. Brix, H.; Schierup, H.-H. The use of aquatic macrophytes in water pollution control. Ambio 1989, 18, 100-107.

16. Culley, D.D., Jr.; Epps, E.A. Use of duckweed for waste treatment and animal feed. J. Water Pollut. Control Fed. 1973, 45, 337-347.

17. Ozimek, T.; Czupryňski, P. Ten years experience of constructed wetlands in Poland. Publ. Inst. Geogr. Univ. Tartu. 2003, 94, 163-169.

18. Gupta, G. Use of water hyacinths in wastewater treatment (A brief literature review). J. Environ. Health 1980, 43, 80-82.

19. Denny, P. Solute movement in submerged angiosperms. Biol. Rev. 1980, 55, 65-92. [CrossRef]

20. Carignan, R.; Kalff, J. Phosphorus sources for aquatic weeds: Water or sediments? Science 1980, 207, 987-989. [CrossRef] [PubMed]

21. Toet, S.; Van Logtestijn, R.S.P.; Schreier, M.; Kampf, R.; Verhoeven, J.T.A. The functioning of a wetland system used for polishing effluent from a sewage treatment plant. Ecol. Eng. 2005, 25, 101-124. [CrossRef]

22. Twilley, R.R.; Kemp, W.M.; Staver, K.W.; Stevenson, J.C.; Boynton, W.R. Nutrient enriccommunitihment of estuarine submersed vascular plant communities. 1. Algal growth and effects on production of plants and associated es. Mar. Ecol. Prog. Ser. 1985, 23, 179-191. [CrossRef]

23. Vymazal, J. Emergent plants used in free water surface constructed wetlands: A review. Ecol. Eng. 2013, 61P, 582-592. [CrossRef]

24. Reed, S.C.; Middlebrooks, E.J.; Crites, R.W. Natural Systems for Waste Management and Treatment, 2nd ed.; McGraw-Hill Book Company: New York, NY, USA, 1995.

25. De Jong, J. The purification of wastewater with the aid of rush or reed ponds. In Biological Control of Water Purification; Pierson, R.W., Ed.; Pennsylvania University Press: Philadelphia, PA, USA, 1976; pp. 133-139.

26. Lakatos, G. Hungary. In Constructed Wetlands for Wastewater Treatment in Europe; Vymazal, J., Brix, H., Cooper, P.F., Green, M.B., Haberl, R., Eds.; Backhuys Publishers: Leiden, The Netherlands, 1998; pp. 191-206.

27. Vymazal, J. Wetlands constructed for wastewater treatment and control. In Encyclopedia of Sustainable Science and Technology; Meyers, R.E., Ed.; Springer: Dordrecht, The Netherlands, 2012; pp. 11891-11910.

28. Hogg, E.H.; Wein, R.W. The contribution of Typha components to floating mat buoyancy. Ecology 1988, 69, 1025-1031. [CrossRef]

29. Thompson, K. Emergent plants of permanent and seasonally flooded wetlands. In The Ecology and Management of African Wetlands; Denny, P., Ed.; Dr. W. Junk: The Hague, The Netherlands, 1985; pp. 43-107.

30. Pallis, M. The structure and history of plavs: The floating fen of the delta of the Danube. Linn. Soc. J. Bot. 1915, 43, 133-290.

31. Lynch, J.; Fox, L.J.; Owen, J.S., Jr.; Sample, D.J. Evaluation of commercial floating treatment wetland technologies for nutrient remediation of stormwater. Ecol. Eng. 2015, 75, 61-69. [CrossRef]

32. Headley, T.R.; Tanner, C.C. Constructed wetlands with floating emergent macrophytes: An innovative stormwater treatment technology. Crit. Rev. Environ. Sci. Technol. 2012, 42, 2261-2310. [CrossRef]

33. Borne, K.E.; Fassman, E.A.; Tanner, C.C. Floating treatment wetlands retrofit to improve stormwater pond performance for suspended solids, copper and zinc. Ecol. Eng. 2013, 54, 173-182. [CrossRef]

34. Tanner, C.C.; Headley, T.R. Components of floating emergent macrophyte treatment wetlands influencing removal of stormwater pollutants. Ecol. Eng. 2011, 37, 474-486. [CrossRef]

35. Bolton, K.G.E.; Greenway, M. Pollutant removal capacity of a constructed Melaleuca wetland receiving primary settled sewage. Water Sci. Technol. 1999, 39, 199-206. [CrossRef]

36. Huang, C.M.; Yuan, C.S.; Yang, W.B.; Yang, L. Temporal variations of greenhouse gas emissions and carbon sequestration and stock from a tidal constructed mangrove wetland. Mar. Pollut. Bull. 2019, 149, 110568. [CrossRef]

37. Vymazal, J. Types of constructed wetlands for wastewater treatment: Their potential for nutrient removal. In Transformations of Nutrients in Natural and Constructed Wetlands; Vymazal, J., Ed.; Backhuys Publishers: Leiden, The Netherlands, 2001 ; pp. 1-93.

38. Seidel, K. Reinigung von Gewässern durch höhere Pflanzen. Deutsche Naturwissenschaft 1966, 12, $289-297$.

39. Kickuth, R. A low-cost process for purification of municipal and industrial waste water. Der Trop. 1982, 83, 141-154. 
40. Haberl, R.; Perfler, R. Nutrient removal in a reed bed system. Wat. Sci. Technol. 1991, 23, 729-737. [CrossRef]

41. Brix, H.; Schierup, H.-H. Sewage treatment in constructed wetlands-Danish experience. Water Sci. Technol. 1989, 21, 1665-1668. [CrossRef]

42. Findlater, B.C.; Hobson, J.A.; Cooper, P.F. Reed bed treatment systems: Performance evaluation. In Constructed Wetlands for Water Pollution Control; Cooper, P.F., Findlater, B.C., Eds.; Pergamon Press: Oxford, UK, 1990; pp. 193-204.

43. Brix, H. Do macrophytes play a role in constructed treatment wetlands? Water Sci. Technol. 1997, 35, 11-17. [CrossRef]

44. Vymazal, J.; Kröpfelová, L. Removal of organics in constructed wetlands with horizontal sub-surface flow: A review of field experience. Sci. Total Environ. 2009, 407, 3911-3922. [CrossRef]

45. Drew, M.C. Plant responses to anaerobic conditions in soil and solution culture. Curr. Adv. Plant Sci. 1979, 11, 179-199.

46. Vymazal, J. Removal of nutrients in constructed wetlands for wastewater treatment through plant harvesting-Biomass and load matter the most. Ecol. Eng. 2020, 155, 105962. [CrossRef]

47. Vymazal, J. Removal of nutrients in various types of constructed wetlands. Sci. Total Environ. 2007, 380, 48-65. [CrossRef]

48. Vohla, C.; Pöldvere, C.; Noorvee, A.; Kuusemets, V.; Mander, Ü. Alternative filter media for phosphorus removal in a horizontal subsurface flow constructed wetlands. J. Environ. Sci. Health 2005, 40, 1251-1264. [CrossRef]

49. Vohla, C.; Koiv, M.; Bavor, H.J.; Chazarenc, F.; Mander, Ü. Filter materials for phosphorus removal from wastewater in treatment wetlands-A review. Ecol. Eng. 2011, 37, 70-89. [CrossRef]

50. Tanner, C.C.; Headley, T.; Dakers, A. Guidelines for the Use of Horizontal Subsurface-Flow Constructed Wetlands in On-Site Treatment of Household Wastewaters; National Institute of Water \& Atmospheric Research: Hamilton, New Zealand, 2011.

51. U.S. EPA. Constructed Wetlands Treatment of Municipal Wastewater; EPA/625/R-99/010; Office of Research and Development: Cincinnati, $\mathrm{OH}, \mathrm{USA}, 2000$.

52. Standard DWA-A 262A; Principles for Dimensioning, Construction and Operation of Wastewater Treatment Plants with Planted and Unplanted Filters for Treatment of Domestic and Municipal Wastewater. The German Association for Water-Wastewater and Waste: Hannef, Germany, 2018.

53. Seidel, K. Neue Wege zur Grundwasseranreicherung in Krefeld. In Hydrobotanische Reinigungsmethode vol. II. GWF Wasser/Abwasser 1965, 30, 831-833.

54. ÖNORM B 2505; Wastewater Treatment Plants-Intermittently Loaded Effluent Filtration Systems (Constructed Wetlands)Application, Dimensioning, Installation, Operation, Service and Inspection. Austrian Standards Institute: Vienna, Austria, 2009.

55. Molle, P.; Boutin, C.; Merlin, G.; Iwema, A. How to treat raw sewage with constructed wetlands: An overview of the French systems. Water Sci. Technol. 2005, 51, 11-21. [CrossRef] [PubMed]

56. Behrends, L.L.; Houke, L.; Bailey, E.; Jansen, P.; Brown, D. Reciprocating constructed wetlands for treating industrial, municipal and agricultural wastewater. Water Sci. Technol. 2001, 44, 399-405. [CrossRef]

57. Gregersen, P.; Brix, H. Zero-discharge of nutrients and water in a willow dominated constructed wetland. Water Sci. Technol. 2001, 44, 407-412. [CrossRef]

58. Gregersen, P.; Gabriel, S.; Brix, H.; Faldager, I. Guidelines for Willow Systems up to 30 PE; Økologisk Byfornyelse og Spildevandsrensning No. 27; Ministry of Environment and Energy: Copenhagen, Denmark, 2003. (In Danish)

59. Vymazal, J. The use of hybrid constructed wetlands for wastewater treatment with special attention to nitrogen removal: A review of a recent development. Water Res. 2013, 47, 4795-4811. [CrossRef]

60. Wallace, S.D.; Knight, R.L. Small-Scale Constructed Wetland Treatment Systems. Feasibility, Design Criteria, and O\&M Requirements; Water Environmental Research Foundation: Alexandria, Virginia, 2006.

61. Monjeau, C. Purifying Water. U.S. Patent 681,884, 18 December 1901.

62. Seidel, K. Pflanzungen zwischen Gewässern und Land. Mitt. Max-Planck Gesselschaft 1953, 17-20.

63. Seidel, K. Abbau von Bacterium coli durch höhere Pflanzen. Naturwissenschaften 1964, 51, 395. [CrossRef]

64. Seidel, K. Zur Problematik der keim-und Pflanzengewasser. Verh. Des Int. Ver. Limnol. 1961, 14, 1035-1039.

65. Kickuth, R. Abwasserreinigung in Wurzelraumverfahren. Wasser Luft Betr. 1980, 11, 21-24.

66. De Jong, J.; Kok, T.; Koridon, A.H. The Purification of Sewage with the Aid of Ponds Containing Bulrushes and Reeds in the Netherlands; Rapport 1977-7 Bbw; Rijskdienst voor de IJsselmeerpolders: Lelystad, The Netherlands, 1977.

67. Greiner, R.W.; De Jong, J. The Use of Marsh Plants for the Treatment of Waste Water in Areas Designated for Recreation and Tourism; Report No. 225; RIJP: Lelystad, The Netherlands, 1984.

68. Hatvani, I.G.; Clement, A.; Kovács, J.; Kovács, I.S.; Korponai, J. Assessing water-quality data: The relationship between the water quality amelioration of Lake Balaton and the construction of its mitigation wetland. J. Great Lakes Res. 2014, 40, 115-125. [CrossRef]

69. Odum, H.T. Self-Organization of Estuarine Ecosystems in Marine Ponds Receiving Treated Sewage. Data from Experimental Pond Studies at Morehead City, North Carolina, 1968-1972. A Data Report; UNC-SG-85-04; University of North Carolina Sea Grant Publications: Chapel Hill, NC, USA, 1985.

70. Sinha, S.N.; Sinha, L.P. Studies on the use of water hyacinth culture in oxidation ponds treating digested sugar wastes and effluents of septic tank. Environ. Health 1969, 11, 197-207.

71. Sheffield, C.W. Water hyacinth for nutrient removal. Hyacinth Control J. 1967, 6, 27-30.

72. Litchfield, D.K. Constructed wetlands for wastewater treatment at Amoco Oil Company's Mandan, North Dakota Refinery. In Constructed Wetlands for Water Quality Improvement; Moshiri, G.A., Ed.; Lewis Publishers: Boca Raton, FL USA, 1993; pp. 485-488. 
73. Kadlec, R.H. Wastewater treatment at the Houghton Lake wetland: Hydrology and water quality. Ecol. Eng. 2009, 35, 1287-1311. [CrossRef]

74. Dinges, R. Upgrading stabilization pond effluent by water hyacinth culture. J. Water Pollut. Control Fed. 1978, 50, 833-845.

75. Ornes, W.H.; Sutton, D.L. Removal of phosphorus from static sewage effluent by water hyacinth. Hyacinth Control J. 1975, 13, 56-58.

76. Wolverton, B.C.; McKown, M.M. Water hyacinth for removal of phenol from polluted waters. Aquat. Bot. 1976, 30, 29-37. [CrossRef]

77. Stewart, E.A., III. Utilization of water hyacinths for control of nutrients in domestic wastewater-Lakeland, Florida. In Aquaculture Systems for Wastewater Treatment: Seminar Proceedings and Engineering Assessment; EPA430/9-80-006; Bastian, R.K., Reed, S.C., Eds.; U.S. EPA: Washington, DC, USA, 1979; pp. 273-293.

78. Fetter, C.W.; Sloey, W.E.; Spangler, F.L. Potential replacement of septic tank drain fields by artificial marsh wastewater treatment systems. Ground Water 1976, 16, 1-7.

79. Pope, P.R. Wastewater Treatment by Rooted Aquatic Plants in Sand and Gravel Trenches; U.S. EPA-600/2-81-091; U.S. Environmental Protection Agency: Cincinnati, OH, USA, 1981.

80. Tilton, D.L.; Kadlec, R.H.; Richardson, C.J. (Eds.) Freshwater Wetlands and Sewage Effluent Disposal; NSF/RANN Conference: Ann Arbor, MI, USA, 1796.

81. Greeson, P.E.; Clark, J.R.; Clark, J.E. (Eds.) Wetland Functions and Values: The State of our Understanding; American Water Resources Association: Minneapolis, MN, USA, 1979.

82. Mitchell, D.S. The potential for wastewater treatment by aquatic plants in Australia. Water Aust. 1976, 5, 15-17.

83. Cooper, P.F. UK experience with reed beds and constructed wetland systems 1985 to 2003. In Proceedings of the International Seminar The Use of Aquatic Macrophytes for Wastewater Treatment in Constructed Wetlands, Lisbon, Portugal, 8-10 May 2003; Dias, V., Vymazal, J., Eds.; ICN and INAG: Lisbon, Portugal, 2003; pp. 403-421.

84. Reddy, K.R.; Smith, W.H. Preface. In Aquatic Plants for Water Treatment and Resources Recovery; Reddy, K.R., Smith, W.H., Eds.; Magnolia Publishing: Orlando, FL, USA, 1987; pp. 1-3.

85. Hammer, D.A.; Bastian, R.K. Wetland ecosystems: Natural water purifiers? In Constructed Wetlands for Wastewater Treatment; Hammer, D.A., Ed.; Lewis Publishers: Chelsea, MI, USA, 1989; pp. 5-19.

86. Cooper, P.F. The use of reed bed systems to treat domestic sewage. The European design and operation guidelines for reed bed treatmentsystems. In Constructed Wetlands for Water Quality Improvement; Moshiri, G.A., Ed.; CRC Press/Lewis Publishers: Boca Raton, FL, USA, 1993; pp. 203-217.

87. Bucksteeg, K. Sewage treatment in helophyte beds-first experience with a new treatment process. Water Sci. Technol. 1987, 19, 1-10. [CrossRef]

88. Schierup, H.-H.; Brix, H.; Lorenzen, B. Wastewater treatment in constructed reed beds in Denamrk-state of the art. In Constructed Wetlands for Water Pollution Control; Cooper, P.F., Findlater, B.C., Eds.; Pergamon Press: Oxford, UK, 1990; pp. $495-504$.

89. Haberl, R.; Perfler, R. Root-zone system: Mannersdorf-New results. In Constructed Wetlands for Wastewater Treatment; Hammer, D.A., Ed.; Lewis Publishers: Chelsea, MI, USA, 1989; pp. 606-621.

90. Cooper, P.F.; Boon, A.G. The use of Phragmites for wastewater treatment by the Root Zone Method: The UK approach. In Aquatic Plants for Water Treatment and Resource Recovery; Reddy, K.R., Smith, W.H., Eds.; Magnolia Publishing: Orlando, FL, USA, 1987; pp. 153-174.

91. Haberl, R.; Perfler, R. Seven years of research work and experiences with wastewater treatment by a reed bed system. In Constructed Wetlands for Water Pollution Control; Cooper, P.F., Findlater, B.C., Eds.; Pergamon Press: Oxford, UK, 1990; pp. 205-214.

92. Coombes, C. Reed bed treatment systems in Anglian Water. In Constructed Wetlands for Water Pollution Control; Cooper, P.F., Findlater, B.C., Eds.; Pergamon Press: Oxford, UK, 1990; pp. 223-234.

93. Cooper, P.F.; Hobson, J.A. Sewage treatment by reed bed systems: The present situation in the United Kingdom. In Constructed Wetlands for Wastewater Treatment; Hammer, D.A., Ed.; Lewis Publishers: Chelsea, MI, USA, 1989; pp. $153-171$.

94. Liénard, A.; Boutin, C.; Esser, D. France. In Constructed Wetlands for Wastewater Treatment in Europe; Vymazal, J., Brix, H., Cooper, P.F., Green, M.B., Haberl, R., Eds.; Backhuys Publishers: Leiden, The Netherlands, 1998; pp. $153-167$.

95. Burka, U.; Lawrence, P. A new community approach to wastewater treatment with higher plants. In Constructed Wetlands for Water Pollution Control; Cooper, P.F., Findlater, B.C., Eds.; Pergamon Press: Oxford, UK, 1990; pp. 359-371.

96. ATV-Hinweis H 262; Behandlung von häuslichen Abwasser in Pflanzenbeeten. Regelwerk Abwasser-Abfall, Gesellschaft zur Förderung der Abwassertechnik: Hennef, Germany, 1989.

97. Cooper, P.F. (Ed.) European Design and Operation Guidelines for Reed Bed Treatment Systems. Prepared for the European Community/European Water Pollution Control Association Emergent Hydrophyte Treatment System Expert Contact Group; Water Research Center Report UI 17; Water Research Center Report: Swindon, UK, 1990.

98. Knight, R.L.; Kadlec, R.H.; Wilhelm, M.; Demgen, F.C.; Gearheart, R.A.; Dyer, J.C.; Jackson, J.; Shearer, J.S.; Richwine, D.; Newberry, L.; et al. Constructed Wetlands for Wastewater Treatment and Wildife Habitat. 17 Case Studies; EPA832-R-93-005; U.S. EPA: Washington, DC, USA, 1993.

99. Silverman, G.S. Development of an urban runoff treatment wetlands in Fremont, California. In Constructed Wetlands for Wastewater Treatment; Hammer, D.A., Ed.; Lewis Publishers: Chelsea, MI, USA, 1989; pp. 669-676. 
100. Wieder, R.K. A survey of constructed wetlands for acid coal mine drainage treatment in the eastern United States. Wetlands 1989, 9, 299-315. [CrossRef]

101. Brodie, G.A.; Hammer, D.A.; Tomljanovich, D.A. Man-made wetlands for acid drainage control. In Proceedings of the 8th Annual National Abandoned Mine Lands Conference, Billings, MT, USA, 10-15 August 1986; pp. 87-105.

102. Hammer, D.A. Designing constructed wetlands systems to treat agricultural nonpoint source pollution. Ecol. Eng. 1992, 1, 49-82. [CrossRef]

103. Stewart, E.A., III; Haselow, D.L.; Wyse, N.M. Review of operations and performance data of five water hyacinth based treatment systems in Florida. In Aquatic Plants for Water Treatment and Resource Recovery; Reddy, K.R., Smith, W.H., Eds.; Magnolia Publishing: Orlando, FL, USA, 1987; pp. 279-288.

104. Watson, J.T.; Reed, S.C.; Kadlec, R.H.; Knight, R.L.; Whitehouse, A.E. Performance expectations and loading rates for constructed wetlands. In Constructed Wetlands for Wastewater Treatment; Hammer, D.A., Ed.; Lewis Publishers: Chelsea, MI, USA, 1989; pp. 319-358.

105. Gersberg, R.M.; Elkins, B.V.; Goldman, C.R. Use of artificial wetlands to remove nitrogen from wastewater. J. Water Pollut. Control Fed. 1984, 56, 152-156.

106. Gersberg, R.M.; Lyons, S.R.; Brenner, R.; Elkins, B.V. Fate of viruses in artificial wetlands. J. Appl. Microbiol. 1987, 53, 731-736. [CrossRef] [PubMed]

107. Thut, R.N. Feasibility of treating pulp mill effluent with a constructed wetland. In Constructed Wetlands for Water Quality Improvement; Moshiri, G.A., Ed.; Lewis Publishers: Boca Raton, FL, USA, 1993; pp. 441-447.

108. U.S. EPA. Design Manual: Constructed Wetlands and Aquatic Plant System for Municipal Wastewater Treatment; EPA 625/1-88/022; U.S. EPA Office of Water: Cincinnati, OH, USA, 1988.

109. Finlayson, M.; Chick, A. Testing the potential of aquatic plants to treat abbatoir effluent. Water Res. 1983, 17, 415-422. [CrossRef]

110. Finlayson, M.; Chick, A.; von Oertzen, I.; Mitchell, D. Treatment of piggery effluent by an aquatic plant filter. Biol. Wastes 1987, 19, 179-196. [CrossRef]

111. Bavor, H.J.; Roser, D.J.; McKersie, S. Nutrient removal using shallow lagon-solid matrix macrophyte systems. In Aquatic Plants for Water Treatment and Resource Recovery; Reddy, K.R., Smith, W.H., Eds.; Magnolia Publishing: Orlando, FL, USA, 1987 ; pp. 227-235.

112. Wood, A. The application of artificial wetlands in South Africa. In Constructed Wetlands for Water Pollution Control; Cooper, P.F., Findlater, B.C., Eds.; Pergamon Pres: Oxford, UK, 1990; pp. 235-244.

113. Salati, E., Jr.; Salati, E.; Salati, E. Wetland projects developed in Brazil. Water Sci. Technol. 1999, 43, 19-25. [CrossRef]

114. Yang, Y.; Zhencheng, X.; Kangping, H.; Junsan, W.; Guizhi, W. Removal efficiency of the constructed wetland wastewater treatment system at Bainikeng, Shenzhen. In Proceedings of the 4th International Conference Wetland Systems for Water Pollution Control, Guangzhou, China, 6-10 November 1994; ICWS Secretariat: Guangzhou, China, $1994 ;$ pp. 94-103.

115. Wang, J.; Cai, X.; Chen, Y.; Yang, Y.; Liang, M.; Zhang, Y.; Wang, Z.; Li, Q.; Liao, X. Analysis of the configuration and the treatment effect of constructed wetland wastewater treatment system for different wastewaters in South China. In Proceedings of the 4th International Conference Wetland Systems for Water Pollution Control, Guangzhou, China, 6-10 November 1994; ICWS Secretariat: Guangzhou, China, 1994; pp. 114-120.

116. Billore, S.K.; Singh, N.; Sharma, J.K.; Dass, P.; Nelson, R.M. Horizontal subsurface flow gravel bed constructed wetland with Phragmites karka in central India. Water Sci. Technol. 1999, 40, 163-171. [CrossRef]

117. Laber, J.; Haberl, R.; Sherstha, R. Two-stage constructed wetland for treating hospital wastewater in Nepal. Water Sci. Technol. 1999, 40, 317-324. [CrossRef]

118. ÖNORM B 2505; Sub-surface flow Constructed Wetlands-Application, Dimensioning, Installation and Operation. Österreichisches Normungsinstitut: Vienna, Austria, 1997. (In German)

119. Danish Environmental Protection Agency. Environmental Guidelines for Root Zone Systems up to 30 PE; Ministry of Environment and Energy: Copenhagen, Denmark, 1999. (In Danish)

120. Tanner, C.C.; Kloosterman, V.C. Guidelines for Constructed Wetland Treatment of Farm Dairy Wastewaters in New Zealand; National Institute of Water and Atmospheric Research Science and Technology Series No. 48; National Institute of Water and Atmospheric Research Science and Technology: Hamilton, New Zealand, 1997.

121. Tousignant, E.; Fankhauser, O.; Hurd, S. Guidance Manual for the Design, Construction and Operations of Constructed Wetlands for Rural Applications in Ontario; Stantec Consulting, University of Guelph and South Nation Conservation: Guelph, ON, Canada, 1999.

122. Wu, S.; Kuschk, P.; Brix, H.; Vymazal, J.; Dong, R. Development of constructed wetlands in performance intensifications for wastewater treatment: A nitrogen and organic matter targeted review. Water Res. 2014, 57, 40-55. [CrossRef]

123. Vymazal, J.; Zhao, Y.; Mander, Ü. Recent research challenges in constructed wetlands for wastewater treatment: A review. Ecol. Eng. 2021, 169, 106318. [CrossRef]

124. Masi, F.; Rizzo, A.; Regelsberger, M. The role of constructed wetlands in a new circular economy, resource oriented, and ecosystem services paradigm. J. Environ. Manag. 2018, 216, 275-284. [CrossRef]

125. Stefanakis, A.I. The role of constructed wetlands as green infrastructure for sustainable urban water management. Sustainability 2019, 11, 6981. [CrossRef]

126. Atanasova, N.; Castellar, J.A.C.; Pineda-Martos, R.; Nika, C.E.; Katsou, E.; Istenič, D.; Pucher, B.; Andreucci, M.B.; Langergraber, G. Nature-based solutions and circularity in cities. Circ. Econ. Sustain. 2021, 1, 319-332. [CrossRef] 
127. Vymazal, J. Do laboratory scale experiments improve constructed wetland treatment technology? Environ. Sci. Technol. 2018, 52, 12956-12957. [CrossRef] [PubMed]

128. Seidel, K. Phenol-Abbau in Wasser durch Scirpus lacustris L. wehrend einer versuchsdauer von 31 Monaten. Naturwissenschaften 1965, 52, 398-406. [CrossRef]

129. Seidel, K. Macrophytes and water purification. In Biological Control of Water Pollution; Tourbier, J., Pierson, R.W., Eds.; Pennsylvania University Press: Philadelphia, PA, USA, 1976; pp. 109-122.

130. Bittmann, M.; Seidel, K. Entwässerung und Aufbereitung von Chemieschlamm mit Hilfe von Pflanzen. GWF 1967, $10,488-491$.

131. Widyanto, L.S. The effect of industrial pollutants on the growth of water hyacinth (Eichhornia crassipes) tropical pest biology program BIOTROP. Proc. Indones. Weed Sci. Conf. 1975, 3, 328-329.

132. Wolverton, B.C.; McDonald, R.C. Water Hyacinths (Eichhornia Crassipes) for Removing Chemical and Photographic Pollutants from Laboratory Wastewaters; NASA Tech. Memorandum TM-X-72731; National Space Technology Laboratories: Bay St. Louis, MS, USA, 1976.

133. Huntsman, B.E.; Solch, J.G.; Porter, M.D. Utilization of Sphagnum sp. dominated bog for coal acid mine drainage abatement. In Geological Society of America 91th Annual Meeting Book of Abstracts; Geological Society of America: Boulder, CO, USA, 1978 ; p. 322.

134. Shroff, K.C. Reuse of water and sludge for cultivation of variety of value added botanical species. In ENPC-IIT Joint Workshop on Strategy and Technology for Water Quality Management; Indian Institute of Technology: Bombay, India, 1982; pp. $379-425$.

135. Wolverton, B.C.; McDonald, R.C. Natural processes for treatment of organic chemical waste. Environ. Prof. 1981, $3,99-104$.

136. Gersberg, R.M.; Lyon, S.R.; Elkins, B.V.; Goldman, C.R. The removal of heavy metals by artificial wetlands. In Proceddings Conference Future of Water Use; AWWA Research Foundation: Denver, CO, USA, 1984; pp. 639-648.

137. Prasad, B.G.S.; Madhavakrishna, W.; Nayudamma, Y. Utilization of water hyacinth in the treatment and disposal of tannery wastewater. In International Conference on Water Hyacinth; Synopsis of Papers: Hyderabad, India, 1983; p. 56.

138. Reddy, K.R.; Campbell, K.L.; Graetz, D.A.; Portier, K.M. Use of biological filters for treating agricultural drainage effluents. J. Environ. Qual. 1982, 11, 591-595. [CrossRef]

139. Gudekar, V.R.; Borkar, L.P.; Kavadia, K.M.; Trivedy, R.K. Studies on the feasibility of removal of sodium pentachlorophenate (SPCP) with water hyacinth. Pollut. Res. 1984, 3, 71-75.

140. Yeoh, B.G. Use of Water Hyacinth in Wastewater Treatment. In Terminal Report; Standard and Industrial Research Institute of Malaysia: Shah Alam, Malaysia, 1983.

141. Wolverton, B.C.; McDonald, R.C.; Marble, L.K. Removal of benzene and its derivatives from polluted water using the reed/microbial filter technique. J. Miss. Acad. Sci. 1984, 29, 119-127.

142. John, C.K. Use of water hyacinth in the treatment of effluents from rubber industry. In Proceedings Conference on Water Hyacinth; UNEP Nairobi: Hyderabad, India, 1983; pp. 699-712.

143. Allender, B.M. Water quality improvement of pulp and paper mill effluents by aquatic plants. Appita 1984, 3, 303-306.

144. Thut, R.N. Utilization of artificial marshes for treatment of pulp mill effluents. Tappi J. 1990, 73, 93-96.

145. Guida, V.G.; Kugelman, I.J. Experiments in wastewater polishing in constructed tidal marshes: Does it work? Are the results predictable? In Constructed Wetlands for Wastewater Treatment; Hammer, D.A., Ed.; Lewis Publishers: Chelsea, MI, USA, 1989; pp. $727-734$.

146. De Zeeuw, W.; Heijnen, G.; De Vries, J. Reed bed treatment as a wastewater (post) treatment alternative in the potato starch industry. In Constructed Wetlands in Water Pollution Control; Cooper, P.F., Findlater, B.C., Eds.; Pergamon Press: Oxford, UK, 1990; pp. 551-553.

147. Wolverton, B.C.; Bounds, B.K. Aquatic plants for $\mathrm{pH}$ adjustment and removal of toxic chemicals and dissolved minerals from waste supplies. J. Miss. Acad. Sci. 1988, 33, 71-80.

148. Van Oostrom, A.J.; Cooper, R.N. Meat processing effluent treatment in surface-flow and gravel-bed constructed wastewater wetlands. In Constructed Wetlands in Water Pollution Control; Cooper, P.F., Findlater, B.C., Eds.; Pergamon Press: Oxford, UK, 1990; pp. 321-332.

149. Staubitz, W.W.; Surface, J.M.; Steenhuis, T.S.; Peverly, J.H.; Lavine, M.J.; Weeks, N.C.; Sanford, W.E.; Kopka, R.J. Potential use of constructed wetlands to treat landfill leachate. In Constructed Wetlands for Wastewater Treatment; Hammer, D.A., Ed.; Lewis Publishers: Chelsea, MI, USA, 1989; pp. 735-742.

150. Birkbeck, A.E.; Reil, D.; Hunter, R. Application of natural and engineered wetlands for treatment of low-strength leachate. In Constructed Wetlands in Water Pollution Control; Cooper, P.F., Findlater, B.C., Eds.; Pergamon Press: Oxford, UK, 1990; pp. 411-418.

151. Vymazal, J. Use of reed-bed system for the treatment of concentrated wastes from agriculture. In Constructed Wetlands in Water Pollution Control; Cooper, P.F., Findlater, B.C., Eds.; Pergamon Press: Oxford, UK, 1990; pp. 347-358.

152. Zachritz, W.H., II.; Jacquez, R.B. Treating intensive aquaculture recycled water with a constructed wetlands filter system. In Constructed Wetlands for Water Quality Improvement; Moshiri, G.A., Ed.; CRC Press/Lewis Publishers: Boca Raton, FL, USA, 1993; pp. 609-614.

153. Machate, T.; Noll, H.; Behrens, H.; Kettrup, A. Degradation of phenanthrene and hydraulic characteristics in a constructed wetland. Water Res. 1997, 31, 554-560. [CrossRef]

154. Salmon, C.; Crabos, J.L.; Sambuco, J.P.; Bessiere, J.M.; Basseres, A.; Caumette, P.; Baccou, J.C. Artificial wetland performances in the purification efficiency of hydrocarbon wastewater. Water Air Soil Pollut. 1998, 104, 313-329. [CrossRef] 
155. Wiessner, A.; Kuschk, P.; Sottmeister, U.; Struckmann, D.; Jank, M. Treating a lignite pyrolysis wastewater in a constructed subsurface flow wetland. Water Res. 1999, 33, 1296-1302. [CrossRef]

156. Grismer, M.E.; Carr, M.A.; Shepherd, H.L. Evaluation of constructed wetland treatment performance for winery wastewater. Water Environ. Res. 2003, 75, 412-421. [CrossRef] [PubMed]

157. Jardinier, N.; Blake, G.; Mauchamp, A.; Merlin, G. Design and performance of experimental constructed wetlands treating coke plant effluents. Water Sci. Technol. 2001, 44, 485-491. [CrossRef]

158. Del Bubba, M.; Lepri, L.; Cincinelli, A.; Griffini, O.; Tabani, F. Linear alkylbenzensulfonates (LAS) removal in a pilot submerged horizontal flow constructed wetland. In Proceedings of the 7th International Conference Wetland Systems for Water Pollution Control, Lake Buena Vista, FL, USA, 11-16 November 2000; University of Florida: Gainesville, FL, USA, 2000 ; pp. 919-925.

159. Yang, L.; Lin, H.Y.; Shih, P.Y. Feasibility of constructed wetlands applied to industrial wastewater recirculating treatment systems. In Proceedings of the 8th International Conference Wetland Systems for Water Pollution Control, Arusha, Tanzania, 16-19 September 2002; University of Dar es Salaam and IWA: Dar es Salaam, Tanzania, 2002; pp. 460-471.

160. Kalibbala, H.M.; Nalubega, M.; Kulabako, R.N. Challenges in the use of constructed wetland in the treatment of industrial wastewater. In Proceedings of the 8th International Conference Wetland Systems for Water Pollution Control, Arusha, Tanzania, 16-19 September 2002; University of Dar es Salaam and IWA: Dar es Salaam, Tanzania, 2002; pp. 504-513.

161. Ye, Z.H.; Lin, Z.-Q.; Whiting, S.N.; de Souza, M.P.; Terry, N. Possible use of constructed wetland to remove selenocyanata, arsenic, and boron from electric utility wastewater. Chemosphere 2003, 52, 1571-1579. [CrossRef]

162. Davies, L.C.; Carias, C.C.; Novais, J.M.; Martins-Dias, S. Phytoremediation of textile effluents containing azo dye by using Phragmites australis in a vertical flow intermittent feeding constructed wetland. Ecol. Eng. 2005, 25, 594-605. [CrossRef]

163. Braeckevelt, M.; Rokadia, H.; Mirschel, G.; Weber, S.; Imfeld, G.; Stelzer, N.; Kuschk, P.; Kastner, M.; Richnow, H.H. Biodegradation of chlorobenzene in a constructed wetland treating contaminated groundwater. In Proceedings of the 10th International Conference Wetland Systems in Water Pollution Control, Lisbon, Portugal, 23-29 September 2006; Dias, V., Vymazal, J., Eds.; MAOTDR: Lisbon, Portugal, 2006; pp. 1927-1935.

164. Yang, L.; Hu, C.C. Treatment of oil-refinery and steel-mill wastewaters by mesocosm constructed wetland system. Water Sci. Technol. 2005, 51, 157-164. [CrossRef]

165. Olguín, E.J.; Sánchez-Galván, G.; Gonzáles-Portela, R.E.; López-Vela, M. Constructed wetland mesocosms for the treatment of diluted sugarcane molasses stillage from ethanol production using Pontederia sagittata. Water Res. 2008, 42, 3659-3666. [CrossRef]

166. Chakraborti, R.K.; Bays, J.S. Natural treatment of high-strength reverse osmosis concentrate by constructed wetlands for reclaimed water use. Water 2020, 12, 158. [CrossRef]

167. Fia, R.; De Matos, A.T.; De Matos, M.P.; Abreu, E.C.; Fia, F.R.L. Treatment of the wastewater of coffee fruit processing in anaerobic filter system followed by constructed wetland system: I-Removal of organic material. Eng. Agrícola 2010, 30, 1191-1202. [CrossRef]

168. Gao, F.; Li, C.; Jin, W.H. Study on saline aquaculture wastewater treatment by constructed wetland. In Proceedings of the International Conference on Electric Communications and Control, Ningbo, China, 9-11 September 2011; pp. 3938-3941.

169. Shi, Y.; Zhang, G.; Liu, J.; Zhu, Y.; Xu, J. Performance of a constructed wetland in treating brackish wastewater from commercial recirculating and super-intensive shrimp growout systems. Bioresour. Technol. 2011, 102, 9416-9424. [CrossRef]

170. Hua, T.; Haynes, R.J.; Zhou, Y.F. Removal of Al, Ga, As, V and Mo from alkaline wastewater using pilot-scale constructed wetlands. Environ. Sci. Pollut. Res. 2019, 26, 35121-35130. [CrossRef] [PubMed]

171. Nguyen, X.C.; Chang, S.W.; Tran, T.C.P.; Nguyen, T.T.N.; Hoang, T.Q.; Banu, J.R.; Al-Muhtaseb, A.H.; La, D.C.; Guo, W.; Ngo, H.H.; et al. Comparative study about the performance of three types of modified natural treatment systems for rice noodle wastewater. Bioresour. Technol. 2019, 282, 163-170. [CrossRef] [PubMed]

172. Gholipour, A.; Zahabi, H.; Stefanakis, A.I. A novel pilot and full-scale constructed wetland study for glass industry wastewater treatment. Chemosphere 2020, 247, 125966. [CrossRef] [PubMed]

173. Rahmadyanti, E.; Audina, O. The performance of hybrid constructed wetland system for treating the batik wastewater. J. Ecol. Eng. 2020, 21, 94-103. [CrossRef]

174. Pratiwi, N.I.; Mukimin, A.; Zen, N.; Septarina, I. Integration of electrocoagulation, adsorption and wetland technology for jewelry industry wastewater treatment. Sep. Purif. Technol. 2021, 279, 119690. [CrossRef]

175. Neurohr, G.A. Use of aquatic macrophytes for sludge treatment. In Proceedings of the 6th Symposium on Wastewater Treatment, Montréal, QC, Canada, 16-17 November 1983; pp. 262-284.

176. Litchfield, D.K.; Schatz, D. Constructed wetlands for wastewater treatment at Amoco Oil Company's Mandan, North Dakota refinery. In Constructed Wetlands for Wastewater Treatment; Hammer, D.A., Ed.; Lewis Publishers: Chelsea, MI, USA, 1989; pp. 233-237.

177. Kickuth, R. Das Wurzelraumverfahren-ein kosten-günstiges Klärverfahren für den dezentralen Einsatz in Kommunen und Gewerbe. Der Trop. 1982, 83, 141-154.

178. Hammer, D.A.; Rogers, P. Treating Fish Rearing Pond Discharge Waters with Artificial Wetlands; Tennessee Valley Authority Report: Knoxville, TN, USA, 1980.

179. Stone, R.W. The presence of iron and manganese-oxidizing bacteria in natural and simulated bogs. In Treatment of Mine Drainage by Wetlands; Burris, J.E., Ed.; The Pennsylvania University: University Park, PA, USA, 1984; pp. 30-36. 
180. Pesavento, B.G. Factors to be considered when constructing wetlands for utilization as biomass filters to remove minerals from solution. In Treatment of Mine Drainage by Wetlands; Burris, J.E., Ed.; The Pennsylvania University: University Park, PA, USA, 1984; pp. $45-49$.

181. Gray, K.R.; Biddlestone, A.J.; Job, G.; Galanos, E. The use of reed beds for the treatment of agricultural effluents. In Constructed Wetlands in Water Pollution Control; Cooper, P.F., Findlater, B.C., Eds.; Pergamon Press: Oxford, UK, 1990; pp. 333-346.

182. Brodie, G.A.; Hammer, D.A.; Tomljanovich, D.A. Constructed wetlands for treatment of ash pond seepage. In Constructed Wetlands for Wastewater Treatment; Hammer, D.A., Ed.; Lewis Publishers: Chelsea, MI, USA, 1989; pp. 211-219.

183. Ailstock, M.S. Utilization and treatment of thermal discharge by establishment of a wetlands plant nursery. In Constructed Wetlands for Wastewater Treatment; Hammer, D.A., Ed.; Lewis Publishers: Chelsea, MI, USA, 1989; pp. 719-726.

184. Rodgers, J.H.; Dunn, A. Developing design guidelines for constructed wetlands to remove pesticides from agricultural runoff. Ecol. Eng. 1992, 1, 83-95. [CrossRef]

185. Surface, M.J.; Peverly, J.H.; Steenhuis, T.S.; Sanford, W.E. Effect of season, substrate composition, and plant growth on landfill leachate treatment in a constructed wetland. In Constructed Wetlands for Water Quality Improvement; Moshiri, G.A., Ed.; Lewis Publishers: Boca Raton, FL, USA, 1993; pp. 461-472.

186. Higgins, J.; Dechaine, L. The use of large sub-surface flow wetlands to treat glycol-contaminated stormwater from aircraft deicing operations. In Proceedings 10th International Conference Wetland Systems for Water Pollution Control, Lisbon, Portugal, 23-29 September 2006; MAOTDR: Lisbon, Portugal, 2006; pp. 1879-1889.

187. Szilagyi, F.; Somlyody, L.; Koncsos, L. Operation of the Kis-Balaton reservoir: Evaluation of nutrient removal rates. Hydrobiologia 1990, 19, 297-305. [CrossRef]

188. Vincent, G. Use of artificial wetlands for the treatment of recreational wastewater. In Proceedings of the 3rd International Conf. Wetland Systems in Water Pollution Control, Sydney, Australia, 11-16 November 1992; pp. 28.1-28.4.

189. Hunter, R.; Birkbeck, A.E.; Coombs, G. Innovative marsh treatment systems for control of leachate and fish hatchery wastewater. In Constructed Wetlands for Water Pollution Improvement; Moshiri, G.A., Ed.; CRC Press/Lewis Publishers: Boca Raton, FL, USA, 1993; pp. 477-484.

190. Vymazal, J. Constructed wetlands for wastewater treatment in the Czech Republic-state of the art. In Proceedings of the 4th International Conferences on Wetland Systems for Water Pollution Control, Guangzhou, China, 6-10 November 1994; pp. 129-137.

191. Schwartz, M.F.; Boyd, C.E. Constructed wetlands for treatment of channel catfish pond effluent. Progress. Fish-Cult. 1995, 57, 255-266. [CrossRef]

192. Anderson, P. Constructed wetland treatment of sugarbeet process wastewater-1993 update-American Crystal Sugar Company. Spec. Group Use Macrophytes Water Pollut. Control Newsl. 1993, 8, 6-7.

193. Cooper, P.F.; Job, G.D.; Green, M.B.; Shutes, R.B.E. Reed Beds and Constructed Wetlands for Wastewater Treatment; WRc Publications: Medmenham, Marlow, UK, 1996.

194. Braskerud, B.C.; Haarstad, K. Screening and retention of thirteen pesticides in a small constructed wetland. Water Sci. Technol. 2003, 48, 267-274. [CrossRef] [PubMed]

195. Swift, J.; Landsdown, R.V. Design of a vegetative system for motorway run-off treatment: Constraints and design criteria. In Proceedings of the 4th International Conference Constructed Wetland Systems for Water Pollution Control, Guangzhou, China, 6-10 November 1994; pp. 697-703.

196. Vymazal, J. Czech Republic. In Constructed Wetlands for Wastewater Treatment in Europe; Vymazal, J., Brix, H., Cooper, P.F., Green, M.B., Haberl, R., Eds.; Backhuys Publishers: Leiden, The Netherlands, 1998; pp. 95-121.

197. Worrall, P. Reed bed for glycol treatment. Spec. Group Use Macrophytes Water Pollut. Control. Newsl. 1995, $12,13-14$.

198. Hill, D.T.; Rogers, J.W. Auburn University constructed wetland for the treatment of poultry lagoon effluent-A case study. In Constructed Wetlands for Animal Waste Treatment. A Manual on Performance, Design and Operation with Case Histories; Payne, V.W.E., Knight, R.L., Eds.; Gulf of Mexico Program; Stennis Space Center: Hancock County, MS, USA, 1997; pp. II-34-II-40.

199. Prystay, W.; Lo, K.V. Assessment of constructed wetlands for the reduction of nitrogen and phosphorus from greenhouse wastewaters. In Proceedings 6th International Conference on Wetlands Systems for Water Pollution Control; Tauk-Tornisielo, S.M., Salati Filho, E., Eds.; Universidade Estadual Paulista: Sao Paulo, Brazil, 1998; pp. 101-114.

200. Novais, J.M.; Martins-Dias, S. Constructed wetlands for industrial wastewater treatment contaminated with nitroaromatic organic compounds and nitrate at very high concentrations. In Proceedings Conference The Use of Aquatic Macrophytes for Wastewater Treatment in Constructed Wetlands; Dias, V., Vymazal, J., Eds.; ICN and INAG: Lisbon, Portugal, 2003; pp. $277-288$.

201. Burgoon, P.S.; Kadlec, R.H.; Henderson, M. Treatment of potato processing wastewater with engineered natural systems. Water Sci. Technol. 1999, 40, 211-215. [CrossRef]

202. Best, E.P.H.; Miller, J.L.; Larson, S.L. Explosives removal from groundwater at the Volunteer Army Ammunition Plant, TN, in small-scale wetland modules. In Wetlands and Remediation; Means, J.L., Hinchee, R.E., Eds.; Battelle Press: Columbus, OH, USA, 2000; pp. 365-373.

203. Behrends, L.L.; Sikora, F.J.; Bader, D.F. Phytoremediation of explosives-contaminated groundwater using constructed wetlands. In Wetlands and Remediation; Means, J.L., Hinchee, R.E., Eds.; Battelle Press: Columbus, OH, USA, 2000; pp. $375-381$.

204. Moore, B.J.; Ross, S.D.; Gibson, D.; Callow, L. Constructed wetlands for treatment of dissolved phase hydrocarbons in cold climates. In Wetlands and Remediation; Means, J.L., Hinchee, R.E., Eds.; Battelle Press: Columbus, OH, USA, 2000 ; pp. 333-340. 
205. Comeau, Y.; Brisson, J.; Réville, J.-P.; Forget, C.; Drizo, A. Phosphorus removal from trout farm effluents by constructed wetlands. Water Sci. Technol. 2001, 44, 55-60. [CrossRef] [PubMed]

206. Kohler, E.A.; Poole, V.L.; Reicher, Z.J.; Turco, R.F. Nutrient, metal and pesticide removal during storm and nonstorm events by a constructed wetland on an urban golf course. Ecol. Eng. 2004, 23, 285-298. [CrossRef]

207. Snyder, J.A.; Mokry, L.E. Chemical industry's constructed wetland-An environmental education success story. In Proceedings of the 7th Internat. Conference Wetland Systems for Water Pollution Control, Lake Buena Vista, FL, USA, 11-16 November 2000; Univeristy of Florida: Gainesville, FL, USA, 2000; pp. 1349-1355.

208. Billore, S.K.; Singh, N.; Ram, H.K.; Sharma, J.K.; Singh, V.P.; Nelson, R.M.; Das, P. Treatment of a molasses based distillery effluent in a constructed wetland in central India. Water Sci. Technol. 2001, 44, 441-448. [CrossRef]

209. Billore, S.K.; Ram, H.; Singh, N.; Thomas, R.; Nelson, R.M.; Pare, B. Treatment performance evaluation of surfactant removal from domestic wastewater in a tropical horizontal subsurface constructed wetland. In Proceedings of the 8th Internat. Conf. Wetland Systems for Water Pollution Control, Arusha, Tanzania, 16-19 September 2002; University of Dar es Salaam: Dar es Salaam, Tanzania, 2002; pp. 393-399.

210. Tanner, C.C.; Long Nguyen, M.; Sukias, J.P.S. Using constructed wetlands to treat subsurface drainage from intensively grazed dairy pastures in New Zealand. Water Sci. Technol. 2003, 48, 207-213. [CrossRef] [PubMed]

211. Kucuk, O.S.; Sengul, F.; Kapdan, L.K. Removal of ammonia from tannery effluents in a reed bed constructed wetland. Water Sci. Technol. 2003, 48, 176-186. [CrossRef]

212. Maine, M.A.; Hadad, H.; Sánchez, G.; Caffaratti, S.; Bonetto, C. Removal efficiency in a constructed wetland for wastewater treatment from a tool factory. In Proceedings of the 10th International Conference Wetland Systems in Water Pollution Control, Lisbon, Portugal, 23-29 September 2006; Dias, V., Vymazal, J., Eds.; MAOTDR: Lisbon, Portugal, 2006; pp. $1753-1761$.

213. Gross, B.; Montgomery-Brown, J.; Naumann, A.; Reinhardt, M. Occurrence and fate of pharmaceuticals and alkylphenol ethoxylate metabolites in an-effluent-dominated river and wetland. Environ. Toxicol. Chem. 2004, 23, 2074-2083. [CrossRef] [PubMed]

214. Kapellakis, I.E.; Tsagarakis, K.P.; Angelakis, A.N. Performance of free water surface constructed wetlands for olive mill wastewater treatment. In Proceedings of the 9th International Conference Wetland Systems for Water Pollution Control, Avignon, France, 26-30 September 2004; ASTEE: Nanterre, France, 2004; pp. 113-120.

215. Bojcevska, H.; Raburu, P.O.; Tonderski, K.S. Free water surface wetlands for polishing sugar factory effluent in western Kenyamacrophyte nutrient recovery and treatment results. In Proceedings of the 10th International Conference Wetland Systems for Water Pollution Control, Lisbon, Portugal, 23-29 September 2006; Dias, V., Vymazal, J., Eds.; MAOTDR: Lisbon, Portugal, 2006; pp. 709-718.

216. Comino, E.; Riggio, V.; Rosso, M. Mountain cheese factory wastewater treatment with the use of a hybrid constructed wetland. Ecol. Eng. 2011, 37, 1673-1680. [CrossRef]

217. Kimani, R.W.; Mwangi, B.M.; Gichuki, C.M. Treatment of flower farm wastewater effluents using constructed wetlands in lake Naivasha Kenya. Indian J. Sci. Technol. 2012, 5, 1870-1878. [CrossRef]

218. Crous, L.; Britz, P. The use of constructed wetland technology in the treatment and beneficiation of brewery effluent for aquaculture. In Proceedings of the 12th International Conference Wetland Systems for Water Pollution Control, Venice, Italy, 4-8 October 2010; Masi, F., Nivala, J., Eds.; IWA: London, UK; IRIDRA Srl and Pan Srl: Padova, Italy, 2010; pp. 1255-1259. 